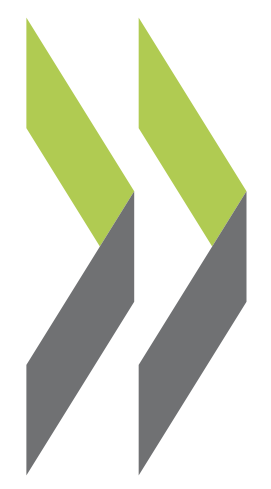

OECD Economics Department Working Papers No. 1139

Gross Earning Inequalities in OECD Countries and Major Non-member Economies: Determinants Henrik Braconier, Jenifer Ruiz-Valenzuela and Future Scenarios 
Organisation de Coopération et de Développement Économiques

Organisation for Economic Co-operation and Development

15-Jul-2014

ECONOMICS DEPARTMENT

English - Or. English

\section{GROSS EARNING INEQUALITIES IN OECD COUNTRIES AND MAJOR NON-MEMBER ECONOMIES: DETERMINANTS AND FUTURE SCENARIOS}

ECONOMICS DEPARTMENT WORKING PAPERS No. 1139

By Henrik Braconier and Jenifer Ruiz-Valenzuela

OECD Working Papers should not be reported as representing the official views of the OECD or of its member countries. The opinions expressed and arguments employed are those of the author(s).

Authorised for publication by Jean-Luc Schneider, Deputy Director, Policy Studies Branch, Economics Department.

All Economics Department Working Papers are available through OECD internet website at www.oecd.org/eco/workingpapers

JT03360446

Complete document available on OLIS in its original format

This document and any map included herein are without prejudice to the status of or sovereignty over any territory, to the delimitation of international frontiers and boundaries and to the name of any territory, city or area. 
ECO/WKP(2014)35

OECD Working Papers should not be reported as representing the official views of the OECD or of its member countries. The opinions expressed and arguments employed are those of the author(s).

Working Papers describe preliminary results or research in progress by the author(s) and are published to stimulate discussion on a broad range of issues on which the OECD works.

Comments on Working Papers are welcomed, and may be sent to OECD Economics Department, 2 rue André-Pascal, 75775 Paris Cedex 16, France, or by e-mail to eco.contact@oecd.org

This document and any map included herein are without prejudice to the status of or sovereignty over any territory, to the delimitation of international frontiers and boundaries and to the name of any territory, city or area.

The statistical data for Israel are supplied by and under the responsibility of the relevant Israeli authorities. The use of such data by the OECD is without prejudice to the status of the Golan Heights, East Jerusalem and Israeli settlements in the West Bank under the terms of international law.

\section{(C) OECD (2014)}

You can copy, download or print OECD content for your own use, and you can include excerpts from OECD publications, databases and multimedia products in your own documents, presentations, blogs, websites and teaching materials, provided that suitable acknowledgment of OECD as source and copyright owner is given. All requests for commercial use and translation rights should be submitted to rights@oecd.org 


\section{ABSTRACT/RÉSUMÉ \\ Gross earning inequalities in OECD countries and major non-member economies: Determinants and future scenarios}

Income and earning inequality has been on the rise in most of the OECD and in many emerging economies since the 1980s. This paper estimates a model of earnings inequality across OECD countries that incorporates determinants of relative demand and supply of more and less-skilled labour. Drawing on OECD data we find that skill-biased technological change - measured as a common cross-country time trend and the level of multi factor productivity - has been the key driver in increasing earning differentials. The analysis also shows that educational attainment has mitigated the impact of skill-biased technological change on earning differentials, but has in most countries been unable to fully compensate. In line with previous OECD analysis, changes in structural policies and labour market institutions, such as deregulation of product and labour markets have exerted upward pressure on inequality. The estimated model is used to decompose historical changes in earning differentials and to construct forward looking scenarios up to 2060. If the common cross-country trend of skill-biased technological change observed during the last 25 years prevails, earning differentials will on average increase by almost $30 \%$ in the OECD by 2060 . Finally, the model is used to simulate the consequences of alternative policy scenarios over the coming 50 years.

JEL classification codes: D31; F68; I24; J24; J31; J38; J58; O33; O38

Keywords: earning inequalities; skill biased technological change; education; labour market institutions; globalization; product market regulation

$* * * * * * * * * * * * * * * * * * * * * * * * * * * * * * * *$

\section{Inégalités de revenus dans les pays de l'OCDE et les grandes économies non membres : Facteurs déterminants et scénarios futurs}

Les inégalités de revenus se creusent dans la plupart des pays de l'OCDE et nombre d'économies émergentes depuis les années 1980. Dans ce document, on évalue un modèle des inégalités de revenu intégrant les déterminants de l'offre et de la demande relatives de main d'œuvre plus qualifiée et moins qualifiée. En analysant la base des données de l'OCDE, on observe que le changement technologiquemesuré comme un effet temporel commun à tous les pays - et le niveau de productivité multifactorielle ont été les principaux moteurs du creusement des écarts de rémunération. L'analyse montre également que le niveau de formation a atténué l'effet du changement technologique sur les écarts de revenus, mais que dans de nombreux pays, il n'a pas suffi à le compenser. Comme l'indiquent de précédentes analyses de l'OCDE, les évolutions des politiques structurelles et des institutions du marché du travail (déréglementation des marchés des produits et du travail notamment) ont exercé une pression à la hausse sur l'inégalité. Le modèle évalué est employé pour décomposer les évolutions historiques des écarts de revenus et pour élaborer des scénarios prospectifs à l'horizon 2060. Si le changement technologique valorisant les compétences observé au cours des 25 dernières années persiste, les écarts de revenus se creuseront de près de $30 \%$ en moyenne d'ici à 2060 dans l'OCDE. Le modèle est par ailleurs utilisé pour simuler les conséquences de scénarios différents dans les 50 prochaines années.

Classification JEL: D31 ; F68 ; I24 ; J24 ; J31 ; J38 ; J58 ; O33 ; O38

Mots clés : inégalités de revenu ; changement technologique valorisant les compétences ; éducation ; institutions du marché du travail ; mondialisation ; réglementation des marchés de produits 


\section{TABLE OF CONTENTS}

\section{GROSS EARNING INEQUALITIES IN OECD COUNTRIES AND MAJOR NON-MEMBER

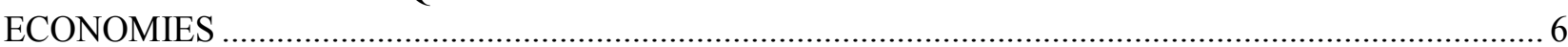

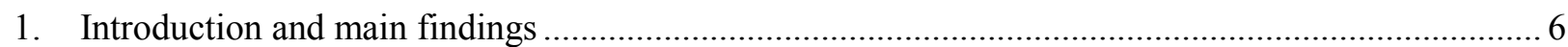

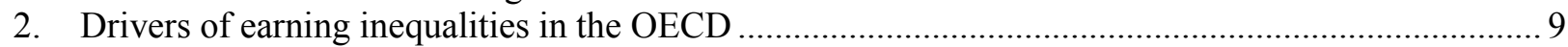

2.1 Tinbergen's model of a race between education and technology provides a useful starting point for explaining rising wage inequality in the OECD......................................................................... 9

2.2 The simple Tinbergen-model performs well in explaining high-to-medium (D9/D5) but not

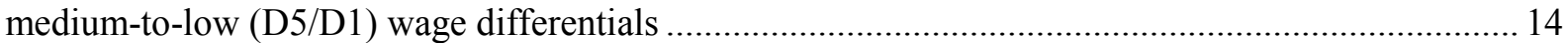

2.3 Extending the simple Tinbergen framework highlights the importance of additional structural factors and policy settings for wage dispersion ............................................................................. 15

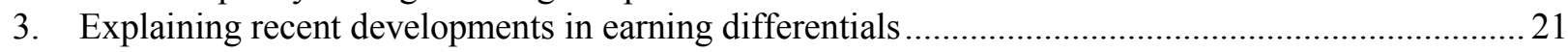

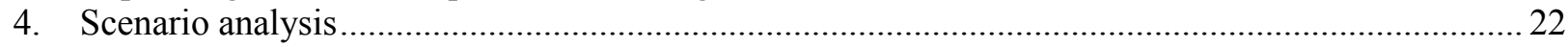

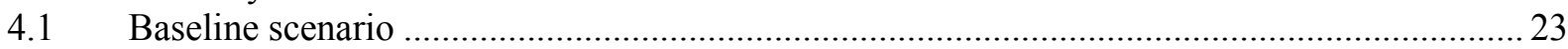

4.2 Alternative scenario 1: Structural policy settings and labour market institutions move to the

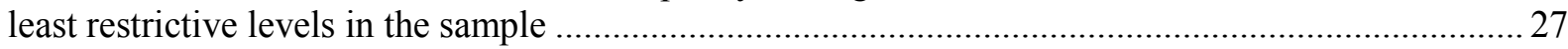

4.3 Alternative scenario 2: Structural policy settings and labour market institutions move to the

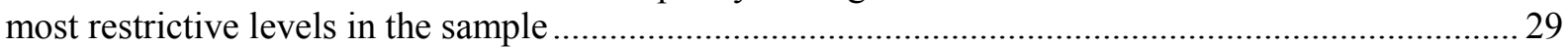

4.4 Alternative scenario 3: Direct and indirect effects of higher trade openness............................29

4.5 Alternative scenario 4: No increases in inequality due to rising educational attainment.......... 32

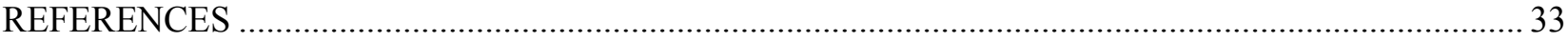

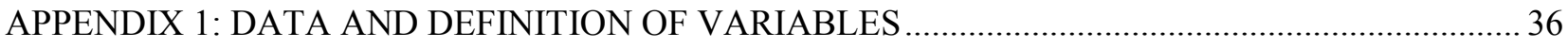

APPENDIX 2: RESULTS OF THE JOINT ESTIMATION OF LOG (D9/D5) AND LOG (D5/D1)......... 39

\section{Tables}

1.

2.

3.

A1.1

A 1.2

A2.1
Tinbergen model Augmented Tinbergen model.

Augmented Tinbergen model after testing down.....

Explanatory variables and data sources

First and last year available in the tables and figures throughout the document. Joint estimation of $\ln (\mathrm{D} 9 / \mathrm{D} 5)$ and $\ln (\mathrm{D} 5 / \mathrm{D} 1)$

\section{Figures}

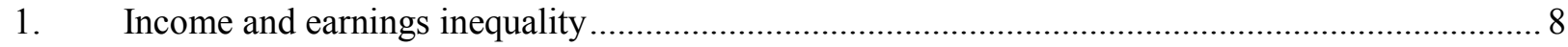

2. Adult skills (literacy) and mean years of schooling, population 15-64 years............................... 11

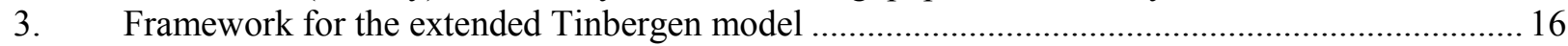

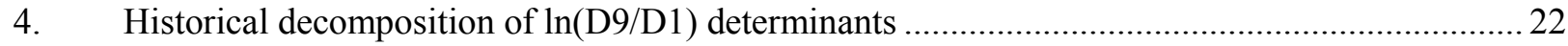

5. Earnings inequality is set to rise further in the baseline scenario ............................................. 25

6. Earnings inequality is driven mainly by a divergence between D9/D5 earnings in the baseline scenario....... 
7. Increase in earnings inequality (D9/D1) if employment protection, union coverage, tax wedges

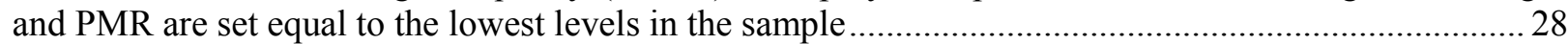
8. Increase in earnings inequality (D9/D1) if employment protection, union coverage, tax wedges

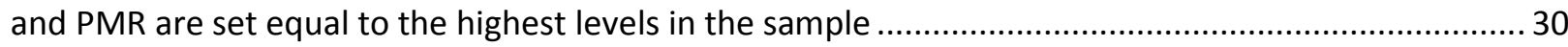

9. Increase in earnings inequality (D9/D1) in the trade scenario .................................................... 31

\section{Boxes}

Box 1. Skill-biased technological change across countries and over time .......................................... 13

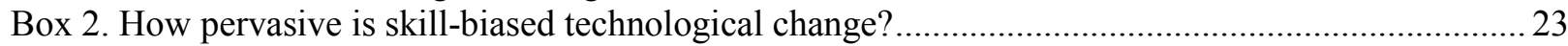




\title{
GROSS EARNING INEQUALITIES IN OECD COUNTRIES AND MAJOR NON-MEMBER ECONOMIES
}

\author{
By \\ Henrik Braconier and Jenifer Ruiz-Valenzuela ${ }^{1}$
}

\section{Introduction and main findings}

1. Inequality has been on the rise in most of the OECD and in many emerging economies since the 1980s (OECD, 2008; OECD, 2011). While the increase seems to have slowed during the crisis, a similar slowdown was also observed during the recession in the early 1990s, followed by a strong resurgence in growing inequality, e.g. in terms of disposable or market income (Figure 1, panel A and B). It therefore seems likely that once the economic recovery takes further hold, incomes may pull apart at a faster pace again. Indeed, recent evidence from the United States suggests that top 1\% income earners have continued to outperform the remaining 99\% since the start of the financial crisis in 2007 (Saez, 2013).

2. Income and earnings inequality can be measured in several ways. This study focuses on dispersion in gross earnings for full-time employees as the measure of inequality. Recent work by the OECD has identified the evolution of earning differentials as the main driver of rising income inequality within the OECD, although significant differences between countries exist. ${ }^{2}$ This focus limits the analysis of drivers of disposable income, as effects of tax and transfer systems, household formation patterns and non-labour income on disposable incomes are not accounted for. ${ }^{3}$ At the same time, focusing on gross earnings highlights the size of the redistributive challenge that may be faced by policy makers in the future.

3. Patterns of income inequality differ not only across countries but also within countries. Recent evidence demonstrates that in most OECD countries, changes in inequality were driven by changes occurring within each half of the income distribution ${ }^{4}$. This implies that increases in overall inequality resulted from higher income inequality among the lower and especially the upper-half of the distribution rather than between them. Along these lines, the effect of technology, trade and globalisation can in return differ greatly across different parts of the distribution, as documented recently ${ }^{5}$ (IMF, 2007; Jaumotte et al., 2013). This paper accounts for such heterogeneities by decomposing the upper and the lower part of the earnings distribution.

4. The paper proceeds in four steps. First, it estimates a model of earnings inequality across OECD countries that incorporates determinants of relative demand and supply of more and less-skilled labour.

1. At the time of writing, Henrik Braconier was a senior economist and Jenifer Ruiz-Valenzuela a consultant in the OECD Economics Department. The authors would like to thank Giuseppe Nicoletti and Nicolas Ruiz as well as colleagues in the Economics Department and the Directorate for Employment, Labour and Social Affairs for their valuable comments and suggestions and Catherine Chapuis and Sarah Michelson for their superb statistical and editorial assistance, respectively.

2. See e.g. OECD (2008), OECD (2011) and Hoeller et al. (2012).

3. See e.g. OECD (2011), Hoeller et al. (2012), and Karabarbounis and Neiman (2013) for analysis of these issues.

4. See e.g. Causa et al. (2014a)

5. These heterogeneities can have a more general impact. As shown in Causa et al. (2014b), the effects of structural policies across the distribution can also vary. 
This model incorporates features from previous OECD analysis, but stresses additional mechanisms - like skill-biased technological change (SBTC) - that have been key drivers in wage inequalities during the past decades. In a second step, the estimated model is used to decompose historical changes in wage inequality. Third, estimates are used to construct earnings inequality scenarios until 2060, based on the OECD longterm growth projections (OECD, 2014) and scenarios of future trade and specialization patterns in Johansson et al. (2013). Fourth, the model is used to simulate the consequences of alternative policy scenarios over the coming 50 years.

5. The forward looking exercises in this paper are a tool for thinking about future tensions and related policy challenges but have no pretension to describe in a realistic way future developments in inequality. In particular, government transfers and taxation policy are assumed to remain unchanged over the next 50 years in the face of rising inequality.

6. Analysis of past trends suggests that while the relative supply of high skilled labour has increased, relative demand for highly-educated labour has outstripped relative supply, leading to rising earnings inequality. Indeed, empirical analysis shows that a common cross-country trend in skill-biased technological change and national increases in multi factor productivity (MFP) have been key drivers of rising earning differentials in most OECD countries during the past decades. SBTC seems to have accelerated since the early-1990, although cyclical variations make patterns difficult to discern. Rising educational attainment has mitigated the impact of these factors, but has in most countries been unable to fully offset them. Changes in structural policies and labour market institutions such as the deregulation of product markets and the easing of employment protection legislation (EPL) have also exerted upward pressure on inequality. Together with rising education levels, increased female participation, openness measured as the joint effect of trade and FDI policies- and GDP per capita have acted as counteracting forces, dampening the increase in inequality.

7. Decomposing the results into the determinants of the upper and the lower part of the earnings distribution, the race between education and technology seems to underlie rising earning differentials in the upper part of the distribution, in line with the polarization/hollowing out of the middle class hypothesis (Goos et al. 2011), where employment and wages have been shrinking for mean or middle skills relative to the extremes. Changes in structural policies and labour market institutions, on the contrary, have mostly affected earning differentials in the bottom half of the distribution. 
Figure 1. Income and earnings inequality

A. Gini coefficient of disposable income (index, Mid-1980s=100)

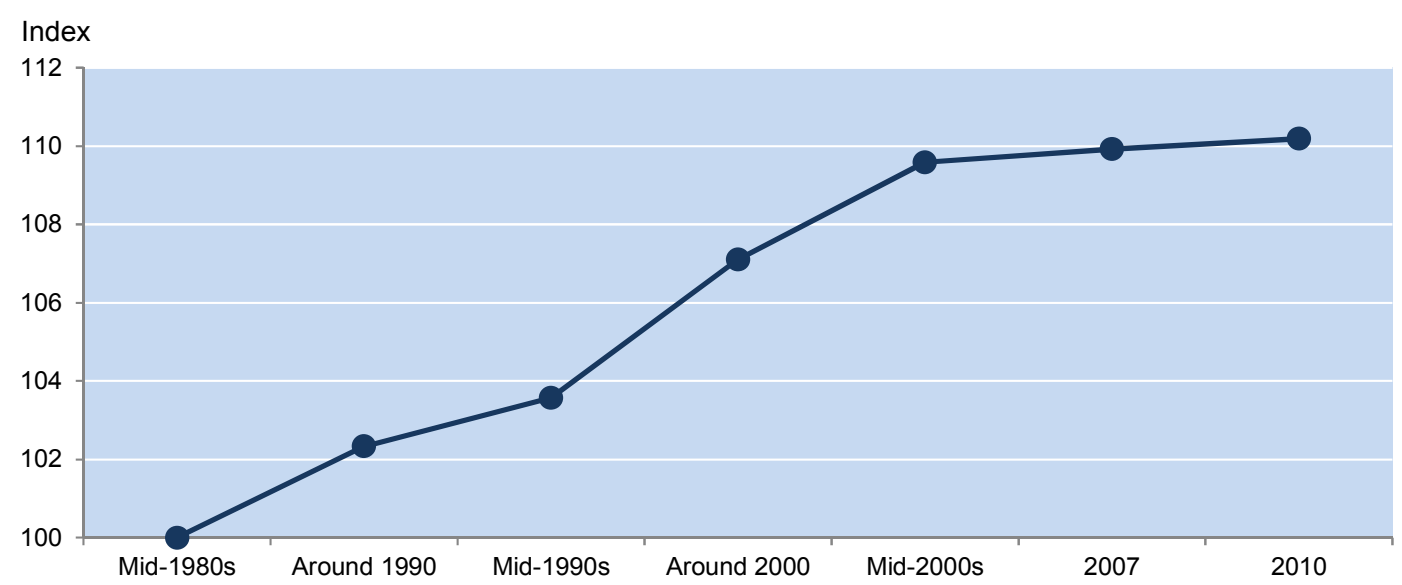

B. Change in gross earnings decile (D9/D1) ratio (late 1970s to late 2000s)

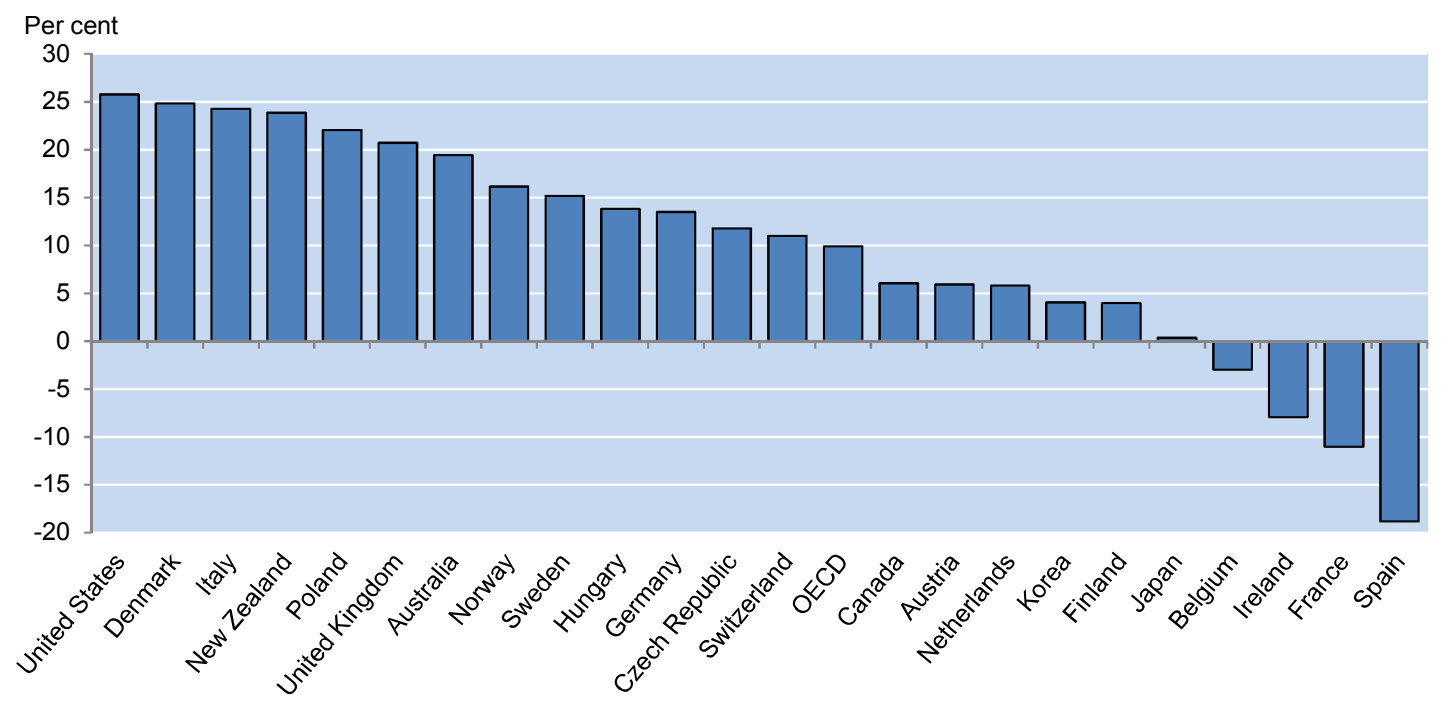

Note: Panel A, 16 OECD countries for which all data points are available. Source: OECD Income Distribution Database (www.oecd.org/social/income-distribution-database.htm). Panel B, data period coverage differs across countries: (1) 1979/1980 to 2007/2008: USA, DNK, GBR, AUS, SWE, NLD, FIN, JPN, FRA; (2) Mid 1980's to 2007/2008: ITA, NZL, DEU, KOR, BEL; Mid 1990's to 2008: POL, NOR, HUN, CZE, CHE, CAN, IRL, ESP; (4) 1980 to 1994: AUT. The value for the OECD is the simple average of the values for the countries in the graph. Source: OECD structure of earnings database.

8. The baseline scenario is based on the most recent OECD long term scenarios on growth, MFP, human capital investment and product market liberalization up until 2060 (OECD, 2014). The analysis shows that if trend SBTC continues at the same rate as observed over the past 25 years in the OECD, earning differentials - measured as the ratio of the upper bound of the $9^{\text {th }}$ decile of the earning distribution for full-time employees to the upper bound of the $1^{\text {st }}$ decile earnings (D9/D1) - will on average increase by almost $30 \%$ in the OECD over the coming fifty years, with individual countries experiencing increases 
between 16 and $41 \%{ }^{6}$. The model predictions suggest that rising earning inequalities over the coming 50 years will mainly be driven by a divergence in D9/D5 earnings, whereas D5/D1 earning differentials will rise only marginally.

9. Using the model estimated with historical data for available OECD countries, projections of earning differentials are obtained for other OECD countries and major non-member economies. Among non-member economies, earning inequalities could increase by $21 \%$ on average up until 2060 . However, this number masks substantial differences in developments across countries and should be treated with caution - especially for emerging economies - as economic structures deviate significantly from in-sample OECD countries.

10. Several alternative scenarios are considered. The first scenario focuses on how an easing of product and labour market regulations and institutions and a lowering of labour taxation to the lowest levels in the OECD area would affect wage dispersion up to 2060. The second scenario investigates how earning inequality would be affected if instead product market regulations and institutions and labour taxation converged to the highest levels prevailing in the OECD. A third simulation compares the direct and indirect effects of increasing trade integration, in line with Johansson and Olaberría (2014). Finally, the role of investment in education for mitigating projected increases in earnings differentials is also explored.

11. The remainder of the paper is structured as follows. Section 2 presents the model(s) for earning differentials together with the estimation(s) and the choice of the final specification. Section 3 decomposes the recent developments in earning differentials and section 4 shows the results for wage dispersion up to 2060 under the baseline and the different alternative scenarios. Section 5 concludes.

\section{Drivers of earning inequalities in the OECD}

\subsection{Tinbergen's model of a race between education and technology provides a useful starting point for explaining rising wage inequality in the $\mathrm{OECD}$}

12. Tinbergen (1974) described wage differentials across educational classes as being driven by a race between demand (technology) and supply (education). To describe the framework, we follow Acemoglu and Autor (2012), assuming a CES production function for the aggregate economy. The total supply of less-educated workers is denoted by $L$, whereas the total supply of more-educated workers (measured as having completed tertiary education) is denoted by $H$. Technology $(A)$ is assumed to be factor augmenting and complements either less $\left(A_{L}\right)$ or more educated workers $\left(A_{H}\right)$.

$Y=\left[\theta\left(A_{L} L\right)^{\frac{\sigma-1}{\sigma}}+(1-\theta)\left(A_{H} H\right)^{\frac{\sigma-1}{\sigma}}\right]^{\frac{\sigma}{\sigma-1}}$

13. Competitive factor markets imply that wages for more and less educated workers are determined by expressions $(2 a)$ and $(2 b)$.

$$
w_{H}=\frac{\partial Y}{\partial H}=\frac{\sigma}{\sigma-1}\left[\theta\left(A_{L} L\right)^{\frac{\sigma-1}{\sigma}}+(1-\theta)\left(A_{H} H\right)^{\frac{\sigma-1}{\sigma}}\right]^{\frac{1}{\sigma-1}}\left(\frac{\sigma-1}{\sigma}(1-\theta) A_{H}^{\frac{\sigma-1}{\sigma}} H^{\frac{-1}{\sigma}}\right)
$$

6. Given the focus on full-time employees in this paper, it should be kept in mind that other mechanisms, such as the full/part-time divide and earnings from self-employment also affect the overall earning differentials. 
$w_{L}=\frac{\partial Y}{\partial L}=\frac{\sigma}{\sigma-1}\left[\theta\left(A_{L} L\right)^{\frac{\sigma-1}{\sigma}}+(1-\theta)\left(A_{H} H\right)^{\frac{\sigma-1}{\sigma}}\right]^{\frac{1}{\sigma-1}}\left(\frac{\sigma-1}{\sigma} \theta A_{L}^{\frac{\sigma-1}{\sigma}} L^{\frac{-1}{\sigma}}\right)$

14. Combining (2a) and (2b) and taking logs produces an equation that shows the key forces in the classical Tinbergen (1974) model. Relative wages are determined by the degree of skill-bias in technology $\left(A_{H} / A_{L}\right)$ and the relative supply of more to less educated workers:

$\ln \omega=\ln \left(\frac{w_{H}}{w_{L}}\right)=\alpha_{0}+\alpha_{1} \ln \left(\frac{A_{H}}{A_{L}}\right)-\alpha_{2} \ln \left(\frac{H}{L}\right)$

15. In the literature (see e.g. Katz and Murphy, 1992; Autor and Acemoglu, 2012) it is often assumed that skill-biased technological change (SBTC) takes place at a constant rate such that $\ln \left(A_{H, t} / A_{L . t}\right)=$ $\gamma_{0}+\gamma_{1} t$. This implies that (3) could be rewritten as:

$\ln \omega_{t}=c_{0}+c_{1} t-c_{2} \ln \left(\frac{H_{t}}{L_{t}}\right)$

16. If production technologies are the same across countries - up to a constant - the model can be written as:

$\ln \omega_{i t}=\alpha_{i}+\beta_{1} t+\beta_{2} \ln \left(\frac{H_{i t}}{L_{i t}}\right)+\varepsilon_{i t}$

17. Alternatively, the assumption that skill biased technological change takes place at a constant rate could be modified to allow for differences in multi factor productivity (MFP) to play a role such that $\ln \left(A_{H, i t} / A_{L, i t}\right)=\gamma_{0}+\gamma_{1} t+\gamma_{2} \ln \left(M F P_{i t}\right)$. Under this formulation, SBTC is driven by a cross-country common trend and a country-specific effect related to MFP. The former can be seen as the global trend in SBTC, meaning that even without domestic SBTC, global SBTC will affect domestic relative earnings. ${ }^{7}$

18. There are several possible explanations to why higher MFP may be associated with the use of more skill-biased technologies. First, SBTC by definition means that new technologies will tend to be more skill-biased than older ones and a high use of new technologies is one of the hallmarks of high MFP countries. Thus, high-MFP countries will tend to use more skill-biased technologies, or experience a higher penetration of skill-biased technologies due to higher absorptive capabilities and stronger economic incentives. Second, higher MFP may be associated with a higher specialisation in skill-intensive activities. Equation (5) can then be rewritten as:

$$
\ln \omega_{i t}=\alpha_{i}+\beta_{1} t+\beta_{2} \ln \left(M F P_{i t}\right)+\beta_{3} \ln \left(\frac{H_{i t}}{L_{i t}}\right)+\varepsilon_{i t}
$$

19. In contrast to most previous work this study employs decile (gross) wage data rather than average wages per educational category as the dependent variable. The main reason for this choice is the better quality of international data on earnings per decile than across occupations (OECD, 2011). From a theoretical perspective, there are pros and cons with both types of dependent variables. Based on equation (3) educational-based categories are clearly more closely related to the ratio of highly-educated to lesseducated workers. On the other hand, skills are not exclusively determined by levels of education (Figure

7. This could also reflect worldwide changing composition in production, or unaccounted-for social trends. 
2). This suggests that (market) skills could be better measured through decile wages. ${ }^{8}$ In terms of analysing wage dispersion, decile data has a clear advantage, as educational category data has to be weighted by the size of each category.

Figure 2. Adult skills (literacy) and mean years of schooling, population 15-64 years

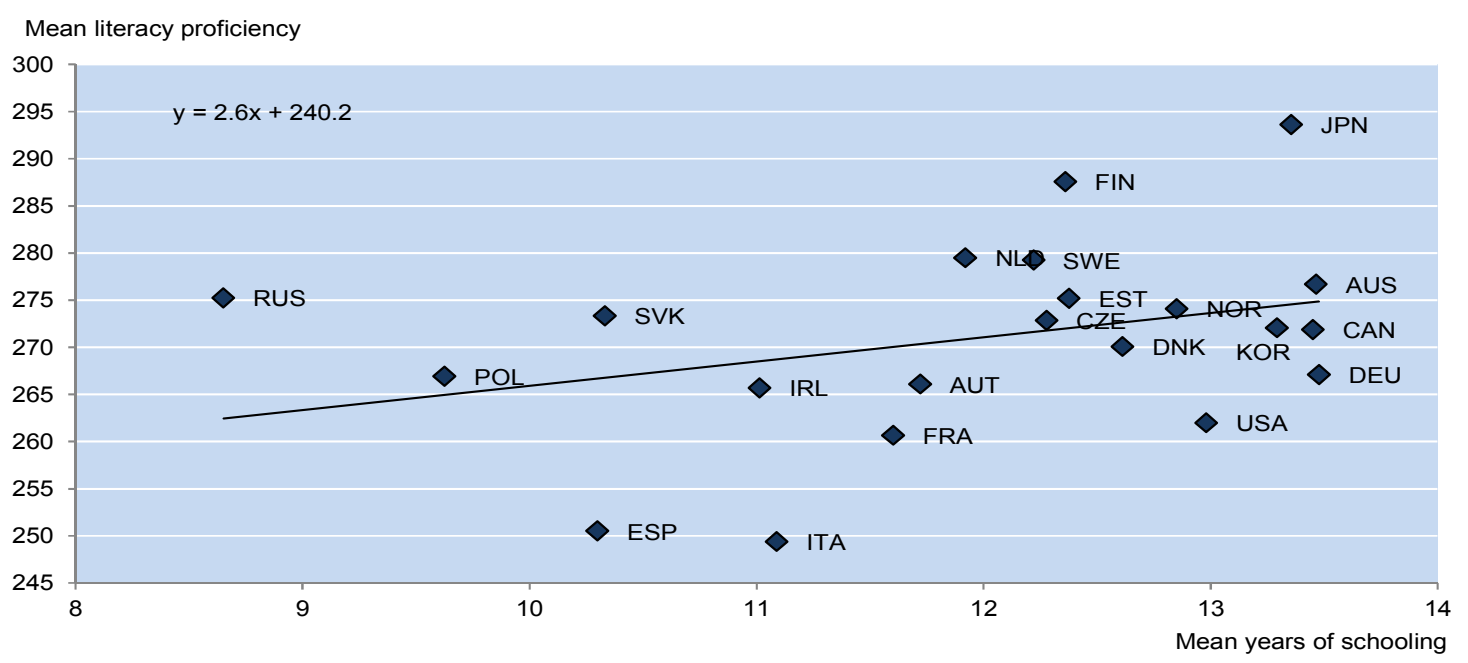

Source: Johansson et al., 2013, OECD (2013), "The Survey of Adult Skills (PIAAC)".

20. Equations (5) and (6) represent the baseline model that is estimated using a panel data set for OECD countries. Data are described in Tables A1.1 and A1.2 in Appendix 1. All estimates are based on fixed-effect estimators, with errors clustered by country. Table 1 (first column) shows the results of estimating equation (5) across 23 OECD countries.

Table 1. Tinbergen model

\begin{tabular}{|c|c|c|c|c|c|c|}
\hline & $\begin{array}{c}\operatorname{In}(\mathrm{D} 9 / \mathrm{D} 1) \\
\beta / \text { t-stat }\end{array}$ & $\begin{array}{c}\text { In(D9/D1) } \\
\beta / \text { t-stat }\end{array}$ & $\begin{array}{c}\text { In(D9/D5) } \\
\beta / \text { t-stat }\end{array}$ & $\begin{array}{c}\text { In(D9/D5) } \\
\beta / \text { t-stat }\end{array}$ & $\begin{array}{c}\ln (\mathrm{D} 5 / \mathrm{D} 1) \\
\beta / \text { t-stat }\end{array}$ & $\begin{array}{c}\operatorname{In}(\mathrm{D} 5 / \mathrm{D} 1) \\
\beta / t \text {-stat }\end{array}$ \\
\hline Trend SBTC & $\begin{array}{c}0.009^{* * *} \\
(5.09)\end{array}$ & $\begin{array}{c}0.008^{\star * \star} \\
(3.75)\end{array}$ & $\begin{array}{c}0.007^{* \star \star} \\
(5.61)\end{array}$ & $\begin{array}{c}0.006^{\star * \star} \\
(4.73)\end{array}$ & $\begin{array}{l}0.003^{*} \\
(2.06)\end{array}$ & $\begin{array}{l}0.002 \\
(1.28)\end{array}$ \\
\hline $\ln (\mathrm{H} / \mathrm{L})$ & $\begin{array}{l}-0.082^{* *} \\
(-2.493)\end{array}$ & $\begin{array}{c}-0.117^{\star * *} \\
(-3.859)\end{array}$ & $\begin{array}{c}-0.065^{\star * *} \\
(-3.033)\end{array}$ & $\begin{array}{c}-0.074^{* * *} \\
(-3.795)\end{array}$ & $\begin{array}{c}-0.051 \\
(-1.714)\end{array}$ & $\begin{array}{l}-0.050^{*} \\
(-1.841)\end{array}$ \\
\hline $\ln (\mathrm{MFP})$ & & $\begin{array}{c}0.314^{* *} \\
(2.19)\end{array}$ & & $\begin{array}{c}0.150^{* *} \\
(2.77)\end{array}$ & & $\begin{array}{l}0.119 \\
(1.43)\end{array}$ \\
\hline $\begin{array}{l}\text { Number of } \\
\text { observations }\end{array}$ & 489 & 427 & 436 & 378 & 436 & 378 \\
\hline Number of countries & 23 & 23 & 22 & 22 & 22 & 22 \\
\hline Adjusted R-squared & 0.35 & 0.41 & 0.46 & 0.46 & 0.09 & 0.08 \\
\hline
\end{tabular}

Note: SBTC stands for skilled biased technological change, $\mathrm{H} / \mathrm{L}$ for high over low skilled workers and MFP for multi factor productivity. Fixed-effects (within) regression. Standard errors adjusted for number of clusters (countries). ${ }^{*},{ }^{* *},{ }^{* * *}$ denote significance at the 10,5 and 1 per cent level, respectively. Countries included and time coverage are described in Table A1.2 in Appendix 1.

8. See e.g. Heckman, Lochner and Todd (2006) on the variations in rates of return to education. 
21. The coefficient for the (log) relative supply of highly-educated to less-educated labour in Table 1 implies an elasticity of substitution of around 12 (column 1), and around 8 (column 2) when ( $\log$ ) MFP is added as an additional component of SBTC. These estimates are high compared to those obtained by Autor and Acemoglu (2012) and Katz and Murphy (1992) for the US economy. But these studies analyse collegehigh school earnings premium - rather than D9/D1-ratios - and the quantitative impact of a given change in relative supply of tertiary educated labour is likely to be bigger on D9/D1-ratios than on college-high school premiums. ${ }^{9}$ Moreover, the present estimates might reflect that small open economies may more easily adjust to changes in skill-composition through changed international specialisation rather than through relative wage adjustments. Goos et al. (2011) estimates the elasticity of substitution between tasks in 16 European countries to be between 1.2 and 9.1 .

22. The estimates imply an annual trend increase in earnings differentials due to trend SBTC of 0.9 per cent per year ( 0.8 per cent when MFP is added to the model).$^{10}$ Moreover, increases in MFP lead to more wage inequality, with a 1 per cent increase in multi factor productivity generating a $0.31 \%$ increase in wage inequality as measured by the D9/D1 earnings decile ratio.

23. Box 1 provides a more in-depth analysis of the effects of trend SBTC, in terms of robustness across countries and over time. In general, the estimates are quite stable, with only a few countries deviating significantly from the cross-country trend. The slowdown in the growth in earning differentials observed in the United States (Autor et al., 2008) does not bear out in the cross-country sample analysed here; if anything the trend seems to have accelerated since the early 1990s, with the difference perhaps reflecting the rising within education-class wage dispersion (Card and Lemieux, 1996). The analysis in Box 1 also suggests a counter-cyclical pattern in SBTC, which could reflect a number of factors.

9. Indeed, the literature on selection into tertiary education based on ability (Heckman, Stixrud and Urzua, 2006), suggests that the marginal individual with tertiary education will push down the average wage for tertiary educated workers both through an indirect effect (the increase in the relative supply of tertiaryeducated workers) and through a direct effect (entry of less productive workers into the pool of the tertiaryeducated workforce). For decile wage data, the latter effect would likely be smaller or non-existent, as it would require the marginal worker to belong to either decile 9 or decile 1.

10. These results are robust to changes in model specification and sample size (see below). This is approximately one-third of the trend estimated by Katz and Murphy (1992) for the US economy 1963-87. More recently Autor et al. (2008) document a slowdown in the US trend increase since the 1990s, perhaps to half the earlier rate (Acemoglu and Autor, 2012). 


\section{Box 1. Skill-biased technological change across countries and over time}

\section{Cross-country variations in SBTC are fairly limited}

Equations (5) and (6) impose the same SBTC trend on all countries in the sample. This is restrictive, as patterns of preferences, technologies and specialization may differ across countries. To gauge the impact of these restrictions, equations (5) and (6) are modified to allow for country-specific trends. Panel A below shows results for equation (6) (those for equation (5) are similar). Most of the estimated coefficients are significantly larger than zero, with point estimates close to the cross-country average.

\section{Stability of (trend) SBTC across countries and time}
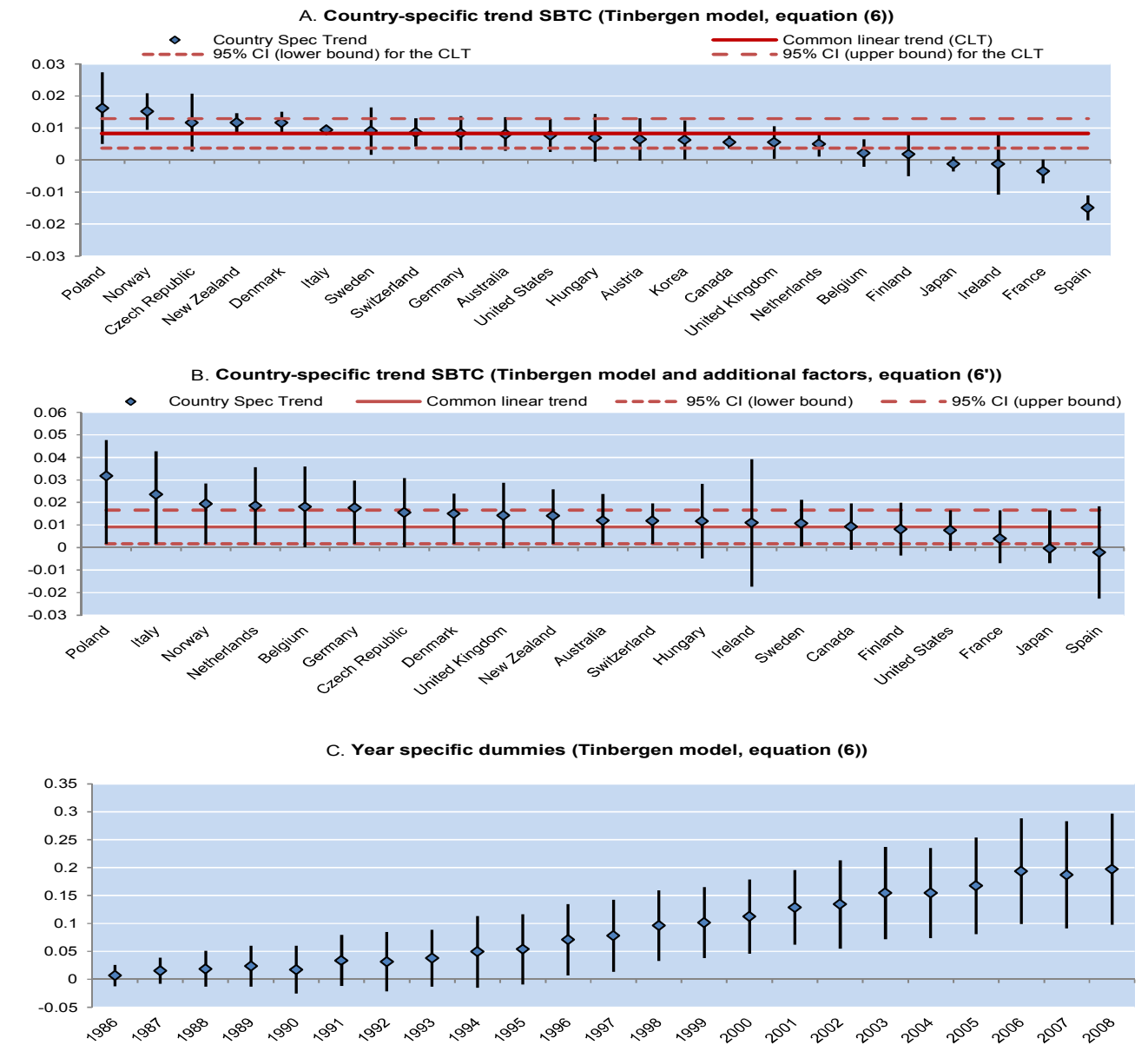

D. Year specific dummies (Tinbergen model and additional factors, equation (6'))

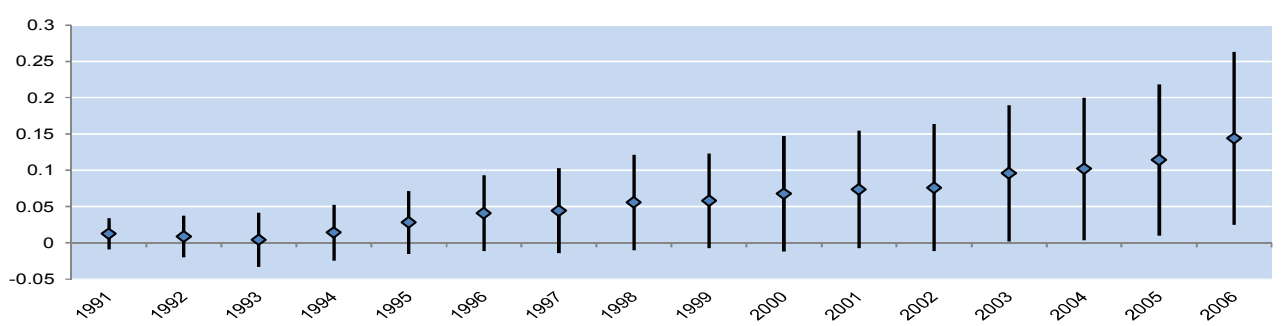

Note: Point estimates (diamonds) and 95\% confidence intervals (vertical bars) from fixed-effects (within) regression. Standard errors adjusted for number of clusters (countries). Countries included and time coverage are described in Table A1.2 in Appendix 1. 
The main exception is Spain, where the effects of estimated trend SBTC are negative and significant. A potential explanation to this result is the growing importance of the construction sector up until the financial crisis, which meant a shift of resources towards less skill-intensive activities. Panel B shows the estimated country-specific trends when additional controls are added (see next section for a description of these additional controls included in the model). The results are largely in line with those from the simpler model, but with a slightly higher mean effect, and lower precision in individual estimates. A drawback when estimating country-specific trends is that the precision of the other estimated coefficients falls. Moreover, possible explanations to country-level differences would be difficult to implement in the forward-looking analysis (such as the Spanish housing-sector example). Therefore, the subsequent analysis will focus on results based on a common trend.

\section{SBTC seems to be counter-cyclical, with no tendency for a weakening trend}

An additional take on robustness of the estimated results is to replace the cross-country trend in equations (5) and (6) by (cross-country) year-specific effects. Results are shown in Panels $C$ and $D$ for equation (6) (the same pattern is found if equation (5) is used instead). Contrary to the findings of Autor et al. (2008) for the US, the estimated year-effects show a steady trend increase, with minor reversals during the downturn in the early 1990s and the financial crisis starting in 2007 . There could be several explanations to these cyclical reversals:

- High-earner incomes may be more volatile, perhaps reflecting a larger share of commissions and regular bonuses for these groups.

- Wage flexibility in the lower part of the earnings distribution may be low, perhaps reflecting minimum wage regulations.

- New technologies are typically embodied in new physical capital. As investment slows during downturns, the pace of (embodied) SBTC slows too.

Abstracting from cyclical patterns, the estimated effects point to an acceleration of SBTC post-1992 rather than the opposite, with a trend rate of $0.6 \%$ for the former period and $1.3 \%$ for the latter, if equations are augmented to include a post-1992 dummy together with an interaction of the trend SBTC term with the post-1992 dummy. Aside from differences in data, divergence with US developments may reflect that the United States adopted new SBTC technologies (e.g. in terms of information technology) in the 1980s and early 1990s, ahead of other OECD countries.

\subsection{The simple Tinbergen-model performs well in explaining high-to-medium (D9/D5) but not medium-to-low (D5/D1) wage differentials}

24. Recently, a lot of attention has focused on the polarization of labour markets, where the lower and (especially) upper tails of the market have performed better in terms of employment and wages than intermediate groups (Autor et al., 2006; Autor and Dorn, 2013; Goos et al., 2011). These patterns have been observed across skills (measured by occupational mean wages) and industries. Simultaneously shrinking employment and wage performance for mean or middle skills relative to the extremes, suggest that demand rather than supply factors are the key drivers behind these changes. Most studies also find that routinization - whereby labour performing routine tasks is being replaced by machinery (as robots) - is the key driver of polarisation, while outsourcing, the composition of product market demand and labour market reforms play lesser roles (see e.g. Autor and Dorn, 2013; Goos et al., 2011). ${ }^{11}$ All in all, studies on polarisation suggest some similarities with the labour demand drivers of rising aggregate earning differentials, with technological and educational factors dominating, and institutions playing a more limited role.

11. Autor et al. (2013), however, find evidence that imports may contribute significantly to relative employment losses together with routinization, although the study does not account for the impact of exports on employment and, hence, cannot describe the full impact of trade. 
25. There are several reasons why it is interesting to investigate more disaggregated earning differentials. First, despite overall similarities, the impact of specific factors (like trade or specific institutions) may deviate from those found for aggregate numbers. Second, the political economy impact of rising earning differentials between top- and medium incomes may differ from those emanating from medium to low differentials. Third, D9/D5-ratios are better proxies for the return to investment in higher education (Braconier et al., 2014).

26. As shown in Table 1 (columns 3-4), the Tinbergen model performs well in explaining high-tomedium (D9/D5) wage differentials. The estimated coefficients imply a slightly smaller effect of trend SBTC, and a higher elasticity of substitution than for the D9/D1 ratio. By contrast, medium-to-low wage differentials (D5/D1) are not very well explained by the Tinbergen model. The estimated coefficients (columns 5 and 6) have the expected sign, but they are estimated with less precision and the explanatory power of the model is low. In line with the polarization/hollowing out of the middle class theories, SBTC seems, therefore, to be a more important driver of inequality in the upper part of the distribution.

\subsection{Extending the simple Tinbergen framework highlights the importance of additional structural factors and policy settings for wage dispersion}

27. The basic Tinbergen model can be extended to allow for additional factors beyond the SBTC component to play a role. ${ }^{12}$ Potentially, these additional factors could help shrinking the impact of the trend component.

28. As discussed by Katz and Murphy (1992), the relative demand for skilled labour could be divided into a within-industry effect - roughly approximating product market supply-side technological factors and a between- industry effect that largely corresponds to product market demand factors, such as preferences and international demand. ${ }^{13}$ Additionally, effective relative supply of skilled labour is not only a function of supply of labour per educational attainment, but also of relative market power in wage setting. Figure 3 summarizes the analytical framework leading to the extended Tinbergen model.

12. The trend component of skill-biased technological change as described by the linear trend in equations (5) and (6) is essentially a residual, akin to the Solow residual in the neoclassic growth model. As such, it is a "measure of our ignorance" that is untestable.

13. Within-industry effects do however also reflect vertical integration due to international supply chains. 
Figure 3. Framework for the extended Tinbergen model

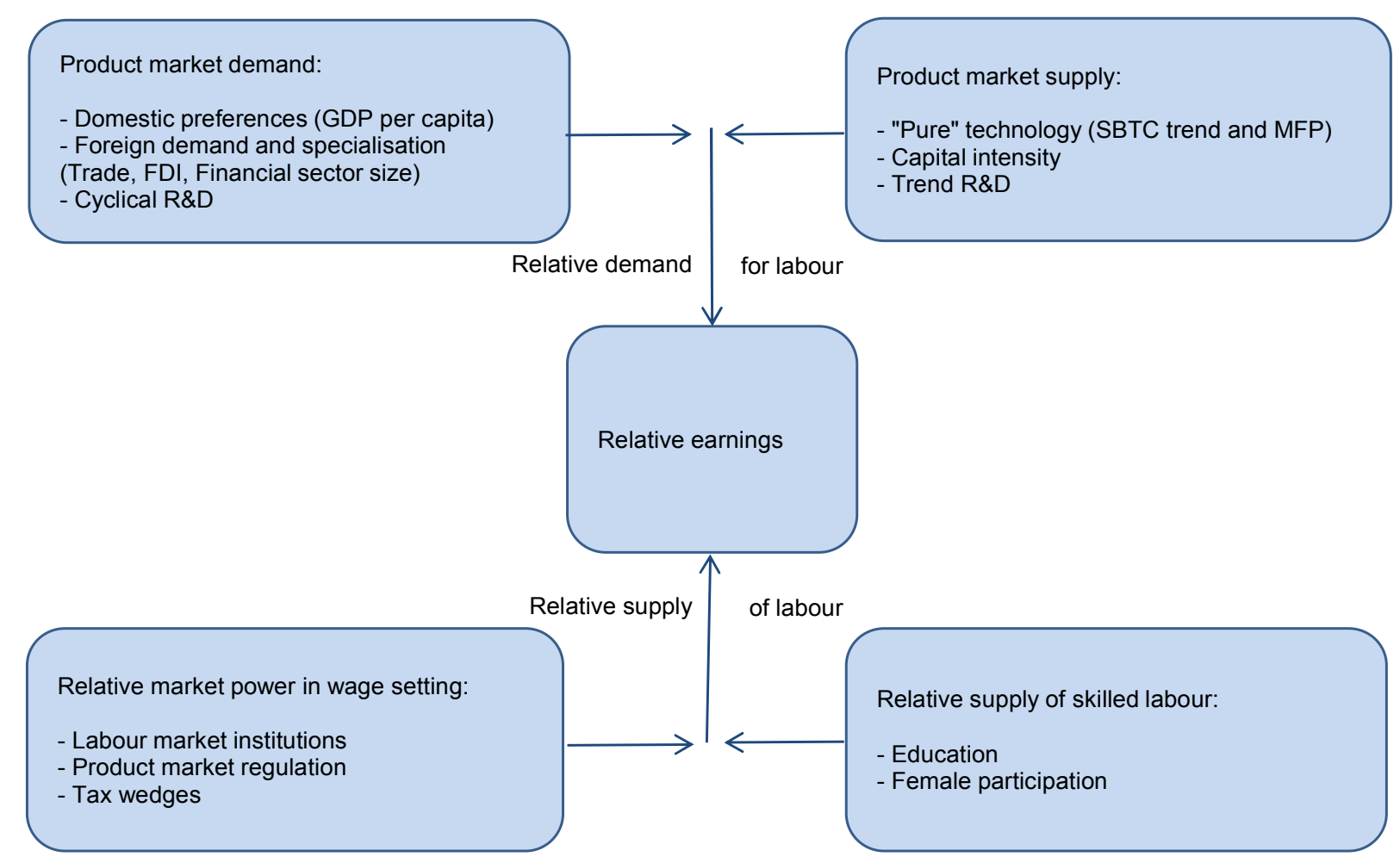

Factors affecting product market supply impact relative demand for labour

29. Several studies have attempted to model the role of technology for earnings dispersion more directly, using R\&D spending and ICT-use (OECD, 2011) or the number of patents per capita (Koske et al. 2012) as proxies for technology. While these variables often have an impact in line with predictions, their overall explanatory power is often limited. One likely reason is that domestic R\&D is a weak proxy for the types of technology that are used, given the global use of technology-embodying capital goods and the time lags between R\&D and widespread use of new technologies. Another explanation is that the trend component SBTC encompasses factors that are wider than just technology, including organizational change and management practices, and the combination of the three.

30. An additional driver could be physical capital, which is omitted from the production function (1). Krussell et al. (2000) point out that due to declines in the price of equipment over time, the use of capital equipment has increased considerably in the last decades. Given that several papers - like Griliches (1969) - have shown that equipment capital seems more complementary to skilled rather than unskilled labour, higher capital intensities could increase levels of earnings inequality. These effects would come on top of the direct income distributional effects of falling relative prices of equipment documented by Karabarbounis and Neiman (2013). As new technologies tend to be embodied in capital goods, the pace of SBTC may vary with the investment cycle, with a possible acceleration when levels of investment are high. In order to address this hypothesis, a measure of capital intensity is incorporated in the empirical model. 


\section{The composition of product market demand can affect relative demand for skills}

31. In equations (5) and (6), the relative demand for skilled and unskilled labour is supply driven, leaving no role for the composition of demand for goods and services. There is, however, ample evidence that production patterns differ across countries and over time, for example relating to the relative importance of different sectors in the economy. First, non-homothetic consumer preferences mean that demand for different products (and hence for different levels of skilled labour) could grow at different rates depending on income levels (Goos et al., 2011), demand in high-income countries being for instance more skill-intensive than in a poorer country. Second, international trade enables countries to specialize in production where they have comparative advantages. OECD (2011) investigates the effects of openness to trade and foreign direct investment (FDI) on wage differentials. De Santis (2002) provides evidence on trade-induced sector-biased technical change, while Johansson et al. (2013) show that countries which specialise in high-skill sectors tend to experience higher wage dispersion ${ }^{14}$. To capture empirically the potential impact of product demand on the relative demand for labour (and hence relative wages) we include GDP per capita levels and indicators of trade exposure and FDI restrictiveness in the regression model.

32. In addition, some studies have highlighted the role played by specific sectors and activities in changing relative demand for different kinds of labour. OECD (2011) investigates the effect of business sector $R \& D$, finding evidence that cyclical variation in $R \& D$ is positively correlated with wage dispersion. Rosnick and Baker (2012) find evidence that the size of the financial sector (measured by its wage share in GDP) increases wage dispersion. ${ }^{15}$ Both variables are also included in the analysis.

Relative supply of skills is a function of both supply of labour per educational attainment and relative market power in wage setting

33. In the simple Tinbergen model relative supply of skills depends on the availability of labour classified according to their highest level of education. Several extensions discussed in OECD (2011) are considered here:

- First, policies that affect labour's market power - like unionisation and levels of employment protection -- may impact wages of skilled and unskilled labour differently (Koeniger and Nunziata, 2007). This may reflect policy settings that are differentiated across the labour force. For instance, low earners are more likely to be affected by legislation on temporary contracts than high-income earners. Also, the impact of any given policy can differ across the earning spectrum. As discussed in OECD (2011), deregulation of product markets may lower market rents available for unions to capture through collective bargaining, leading to greater wage dispersion.

- Second, higher tax wedges will increase labour costs for employers and lower take-home pay, and this might discourage especially employment in low-paid jobs (OECD, 2011). Fewer low-income employees would increase the share of high-skilled labour and drive down wage differentials.

- Third, characteristics of the labour force, other than educational background, may also affect earning differentials. For instance, higher female participation tends to lower wage dispersion

14. The data available to construct skill biased specialization indices and account for specialisation patterns reduces the sample considerably, both at the country and time dimension level. For this reason, an indicator for skill biased specialization is not introduced in the current analysis. Introducing this variable, though, does not change the main predictions regarding the two main variables of the Tinbergen model.

15. This result could alternatively be interpreted as a labour supply factor, with monopoly-rents flowing to high-earners in the financial sector. 
(OECD, 2011): as income distribution among females is more equal than among men, an increasing female share tends to increase the share of wage earners that are closer to the mean. ${ }^{16}$

34. Accounting for all these potential effects results in a modified model specification that includes additional explanatory variables $\left(x_{i t}\right)$, among which we also add the output gap to capture potential business cycle effects:

$$
\ln \omega_{i t}=\alpha_{i}+\beta_{1} t+\beta_{2} \ln \left(M F P_{i t}\right)+\beta_{3} \ln \left(\frac{H_{i t}}{L_{i t}}\right)+x_{i t}^{\prime} \gamma+\varepsilon_{i t}
$$

\section{Empirical results based on the augmented model}

35. Results from the extended Tinbergen model are shown in Table 2. The overall fit of the regression improves, highlighting the importance of (some of the) added variables, while the coefficients for trend SBTC and $(\log )$ multifactor productivity remain statistically significant and of similar magnitude. The magnitude of the coefficient of the relative supply of skilled labour is smaller (in the D9/D1 regression), implying an even higher elasticity of substitution. As in the simple Tinbergen specification, the race between technology and education affects mainly the upper part of the earnings distribution.

16. This only applies if the means of males and females are not too different. 
ECO/WKP(2014)35

Table 2. Augmented Tinbergen model

\begin{tabular}{|c|c|c|c|}
\hline & $\begin{array}{c}\text { In(D9/D1) } \\
\beta / \text { t-stat }\end{array}$ & $\begin{array}{c}\ln (\mathrm{D} 9 / \mathrm{D} 5) \\
\beta / \mathrm{t}-\mathrm{stat}\end{array}$ & $\begin{array}{c}\ln (\mathrm{D} 5 / \mathrm{D} 1) \\
\beta / \text { t-stat }\end{array}$ \\
\hline Trend SBTC & $\begin{array}{l}0.008^{*} \\
(1.82)\end{array}$ & $\begin{array}{c}0.006^{* * *} \\
(3.35)\end{array}$ & $\begin{array}{l}0.002 \\
(0.58)\end{array}$ \\
\hline In (MFP) & $\begin{array}{c}0.357^{* *} \\
(2.18)\end{array}$ & $\begin{array}{l}0.108 \\
(1.23)\end{array}$ & $\begin{array}{l}0.064 \\
(0.55)\end{array}$ \\
\hline In (Capital intensity) & $\begin{array}{l}0.015 \\
(0.25)\end{array}$ & $\begin{array}{l}0.013 \\
(0.66)\end{array}$ & $\begin{array}{l}0.019 \\
(0.44)\end{array}$ \\
\hline In (Trend R \& D) & $\begin{array}{c}-0.008 \\
(-0.231)\end{array}$ & $\begin{array}{c}-0.004 \\
(-0.384)\end{array}$ & $\begin{array}{l}0.046^{*} \\
(2.08)\end{array}$ \\
\hline In (GDP pc) & $\begin{array}{c}-0.29 \\
(-1.364)\end{array}$ & $\begin{array}{c}-0.049 \\
(-0.533)\end{array}$ & $\begin{array}{c}-0.141 \\
(-0.819)\end{array}$ \\
\hline In (Trade) & $\begin{array}{c}-0.032 \\
(-0.443)\end{array}$ & $\begin{array}{l}-0.067^{* *} \\
(-2.836)\end{array}$ & $\begin{array}{c}-0.028 \\
(-0.530)\end{array}$ \\
\hline In (FDI restrictiveness index) & $\begin{array}{l}0.015 \\
(0.61)\end{array}$ & $\begin{array}{l}-0.033^{* *} \\
(-2.116)\end{array}$ & $\begin{array}{c}0.094^{* * *} \\
(3.39)\end{array}$ \\
\hline Cyclical R \& D & $\begin{array}{l}0.001^{*} \\
(2.06)\end{array}$ & $\begin{array}{c}0.001^{* *} \\
(2.62)\end{array}$ & $\begin{array}{l}0.000 \\
(0.66)\end{array}$ \\
\hline In (Financial Compensation) & $\begin{array}{l}0.057 \\
(1.04)\end{array}$ & $\begin{array}{l}0.011 \\
(0.53)\end{array}$ & $\begin{array}{l}0.013 \\
(0.30)\end{array}$ \\
\hline In (HS/LS) & $\begin{array}{l}-0.067^{* *} \\
(-2.373)\end{array}$ & $\begin{array}{c}-0.050^{* * *} \\
(-3.195)\end{array}$ & $\begin{array}{c}-0.01 \\
(-0.769)\end{array}$ \\
\hline In (Female Participation) & $\begin{array}{l}-0.495^{* *} \\
(-2.353)\end{array}$ & $\begin{array}{c}-0.044 \\
(-0.315)\end{array}$ & $\begin{array}{l}-0.375^{\star} \\
(-1.792)\end{array}$ \\
\hline In (PMR) & $\begin{array}{l}-0.061^{* *} \\
(-2.203)\end{array}$ & $\begin{array}{l}0.015 \\
(1.63)\end{array}$ & $\begin{array}{c}-0.088^{* * *} \\
(-3.424)\end{array}$ \\
\hline In (Union Coverage) & $\begin{array}{l}-0.054^{*} \\
(-1.783)\end{array}$ & $\begin{array}{c}-0.050^{\star \star \star} \\
(-3.767)\end{array}$ & $\begin{array}{l}0.021 \\
(0.73)\end{array}$ \\
\hline EPL & $\begin{array}{l}-0.046^{* *} \\
(-2.249)\end{array}$ & $\begin{array}{c}-0.001 \\
(-0.124)\end{array}$ & $\begin{array}{l}-0.035^{*} \\
(-1.795)\end{array}$ \\
\hline In (Tax Wedges) & $\begin{array}{l}-0.085^{\star *} \\
(-2.383)\end{array}$ & $\begin{array}{l}0.001 \\
(0.03)\end{array}$ & $\begin{array}{l}-0.080^{*} \\
(-1.821)\end{array}$ \\
\hline Output gap & $\begin{array}{l}0.002 \\
(0.39) \\
\end{array}$ & $\begin{array}{l}0.001 \\
(0.73)\end{array}$ & $\begin{array}{l}0.002 \\
(0.63) \\
\end{array}$ \\
\hline Number of observations & 256 & 226 & 226 \\
\hline Number of countries & 19 & 19 & 19 \\
\hline Adjusted R-squared & 0.499 & 0.73 & 0.322 \\
\hline
\end{tabular}

Note: Point estimates from fixed-effects (within) regression. Given that the number of observations available is not the same for the 3 equations, the sum of the results in columns 2 and 3 does not coincide with the coefficients in column 1 , although in most cases they are of a similar magnitude. Standard errors adjusted for number of clusters (countries). ${ }^{*}$, **, ${ }^{* * *}$ denote significance at the 10,5 and 1 per cent level, respectively. Countries included and time coverage are described in Table A1.2 in Appendix 1. The description of the variables and sources can be found in Table A1.1 in Appendix 1 
36. As the coefficients of some explanatory variables are insignificant in all regressions the model is simplified by sequentially removing those variables. ${ }^{17}$ The first variable removed following this procedure is the measure of capital intensity, followed by the share of compensation going to the financial sector and the output gap. Regression results for the simplified model, which constitutes the basis for the analysis in the next sections are shown in Table 3.

Table 3. Augmented Tinbergen model after testing down

\begin{tabular}{|c|c|c|c|c|}
\hline & $\begin{array}{c}\operatorname{In}(\mathrm{D} 9 / \mathrm{D} 1) \\
\beta / t-s t a t\end{array}$ & $\begin{array}{c}\ln (\mathrm{D} 9 / \mathrm{D} 5) \\
\beta / \text {-stat }\end{array}$ & $\begin{array}{c}\text { In(D5/D1) } \\
\beta / \text { t-stat }\end{array}$ & $\begin{array}{c}\ln (\mathrm{D} 9 / \mathrm{D} 5)+\ln (\mathrm{D} 5 / \mathrm{D} 1) \\
\text { Sum of } \beta\end{array}$ \\
\hline Trend SBTC & $\begin{array}{c}0.009^{* *} \\
(2.55)\end{array}$ & $\begin{array}{c}0.007^{* * *} \\
(3.61)\end{array}$ & $\begin{array}{l}0.002 \\
(0.60)\end{array}$ & 0.009 \\
\hline In (MFP) & $\begin{array}{c}0.364^{* *} \\
(2.14)\end{array}$ & $\begin{array}{l}0.188^{*} \\
(1.79)\end{array}$ & $\begin{array}{l}0.076 \\
(0.71)\end{array}$ & 0.264 \\
\hline In (Trend R \& D) & $\begin{array}{l}-0.012 \\
(-0.386)\end{array}$ & $\begin{array}{l}-0.002 \\
(-0.210)\end{array}$ & $\begin{array}{c}0.041^{* *} \\
(2.36)\end{array}$ & 0.039 \\
\hline In (GDP pc) & $\begin{array}{l}-0.269^{*} \\
(-1.846)\end{array}$ & $\begin{array}{l}-0.096 \\
(-0.869)\end{array}$ & $\begin{array}{l}-0.074 \\
(-0.649)\end{array}$ & -0.17 \\
\hline In (Trade) & $\begin{array}{l}-0.031 \\
(-0.620)\end{array}$ & $\begin{array}{l}-0.055^{\star * *} \\
(-2.869)\end{array}$ & $\begin{array}{l}-0.028 \\
(-0.689)\end{array}$ & -0.083 \\
\hline In (FDI restrictiveness index) & $\begin{array}{l}0.014 \\
(0.57)\end{array}$ & $\begin{array}{l}-0.028 \\
(-1.613)\end{array}$ & $\begin{array}{c}0.087^{\star \star *} \\
(3.33)\end{array}$ & 0.059 \\
\hline Cyclical R \& D & $\begin{array}{l}0.001^{* *} \\
(2.52)\end{array}$ & $\begin{array}{c}0.001^{* * *} \\
(3.54)\end{array}$ & $\begin{array}{l}0.000 \\
(0.95)\end{array}$ & 0.001 \\
\hline In (HS/LS) & $\begin{array}{l}-0.067^{\star *} \\
(-2.471)\end{array}$ & $\begin{array}{l}-0.041^{*} \\
(-2.081)\end{array}$ & $\begin{array}{l}-0.025^{\star} \\
(-1.877)\end{array}$ & -0.066 \\
\hline In (Female Participation) & $\begin{array}{l}-0.442^{*} \\
(-1.780)\end{array}$ & $\begin{array}{l}0.029 \\
(0.14)\end{array}$ & $\begin{array}{l}-0.423^{* *} \\
(-2.360)\end{array}$ & -0.394 \\
\hline In (PMR) & $\begin{array}{l}-0.063^{\star *} \\
(-2.374)\end{array}$ & $\begin{array}{l}0.022 \\
(1.43)\end{array}$ & $\begin{array}{c}-0.092^{* * *} \\
(-4.055)\end{array}$ & -0.07 \\
\hline In (Union Coverage) & $\begin{array}{l}-0.049 \\
(-1.636)\end{array}$ & $\begin{array}{c}-0.049^{* * *} \\
(-3.151)\end{array}$ & $\begin{array}{l}0.021 \\
(0.92)\end{array}$ & -0.028 \\
\hline EPL & $\begin{array}{l}-0.035^{\star} \\
(-1.756)\end{array}$ & $\begin{array}{c}0 \\
(-0.017)\end{array}$ & $\begin{array}{l}-0.033^{\star *} \\
(-2.121)\end{array}$ & -0.033 \\
\hline In (Tax Wedges) & $\begin{array}{l}-0.093^{\star *} \\
(-2.750) \\
\end{array}$ & $\begin{array}{c}-0.023 \\
(-0.622) \\
\end{array}$ & $\begin{array}{l}-0.069^{*} \\
(-1.953) \\
\end{array}$ & -0.092 \\
\hline Number of observations & 276 & 246 & 246 & \\
\hline Number of countries & 21 & 21 & 21 & \\
\hline Adjusted R-squared & 0.502 & 0.684 & 0.305 & \\
\hline
\end{tabular}

Note: Point estimates from fixed-effects (within) regression. Given that the number of observations available is not the same for the 3 equations, the sum of the results in columns 2 and 3 does not coincide with the coefficients in column 1 , although in most cases they are of a similar magnitude. Standard errors adjusted for number of clusters (countries). ${ }^{*},{ }^{* *}$, ${ }^{* * *}$ denote significance at the 10,5 and 1 per cent level, respectively. Countries included and time coverage are described in Table A1.2 in Appendix 1. The description of the variables and sources can be found in Table A1.1 in Appendix 1.

37. Focusing on the supply and demand side explanatory variables added to the extended Tinbergen model, the following results are noteworthy:

- On the product market supply side, trend R\&D is not significant in the D9/D1 equation but has the expected positive (small) impact on earnings inequality in the D5/D1 equation.

17. Based on their t-statistic, a variable is removed when its coefficient is not significant at least at the $10 \%$ level in any of the three equations. If there are several such variables, the variable that has the least significant coefficient overall is removed first. 
- On the product market demand side, GDP per capita has a (weakly) significant impact on earnings differentials in the D9/D1 equation.

- Trade exposure and FDI restrictiveness have no impact on the D9/D1 equation. However, higher trade seems to reduce inequality on the upper part of the distribution, whereas fewer restrictions to FDI are found to decrease inequality on the lower part. These results are in line with Jaumotte et al. (2013) who find that trade integration is associated with a reduction in inequality. However, empirical evidence on the effects of the globalisation variables (trade and FDI) on inequality is rather inconclusive. ${ }^{18}$ For instance, earlier findings in OECD (2011) suggest that results may depend on the degree of disaggregation of the trade openness variable and on the overall specification of the regression model. Hence, the effects of globalisation on inequality deserve further analysis.

- Cyclically higher R\&D tends to increase earning differentials in the top half of the distribution, likely reflecting rising demand for skilled labour.

- On the relative labour supply side, the results largely confirm those presented in OECD (2011), with employment protection, the degree of unionisation, higher tax wedges and restrictive product market regulations contributing to lower wage differentials. Except for the degree of unionisation, an increase in the variables just mentioned leads to lower wage differentials in the bottom half of the distribution, likely because they have a bigger impact on low income earners (Koske et al., 2012).

- The female employment share has a negative and significant impact concentrated on the lower part of the earnings distribution.

38. The development of $(\log )$ D9/D1 differentials can be explained also by the sum of the coefficients in $(\log )$ D9/D5 and $(\log )$ D5/D1 respectively (column 4 of table 3). ${ }^{19}$ Due to differences in the sample size, the sum of the coefficients does not coincide exactly with the coefficients in column 1 . However, the results point in the same direction and are not markedly different in terms of the historical decomposition and scenarios shown in sections 3 and 4 . Thus, the results in the remaining sections will be based on the D9/D1 estimates in columns 1 of Table 3.

\section{Explaining recent developments in earning differentials}

39. Figure 4 shows the decomposition of the average annual change in (log) D9/D1 earnings differentials between the early to mid-1990s and 2006 based on estimated coefficients and changes in exogenous variables. The variables in Table 3 have been grouped into fewer categories in order to ease interpretation. Different counteracting forces underlie historical wage developments. Technology measured as the joint effect of trend SBTC, MFP levels and the trend component of business R\&D - and changes in structural policies and labour market institutions have exerted upward pressure on the degree of

18. According to the Stolper-Samuelson theorem, trade liberalization is expected to increase inequality in advanced economies as the price of low-skill labour products diminishes with increased openness. Koske et al. (2012) point out that while a positive link between globalisation and inequality is supported by a growing body of firm-level studies, it is more difficult to establish a robust link between globalisation and inequality at the aggregate level, and cite different studies that reach opposite conclusions. For an analysis of the link between trade, FDI and inequality based on a different model specification, see OECD (2011).

19. Table A2.1 in Appendix 2 shows the results when the equations are estimated jointly as seemingly unrelated regression equations (SURE). The coefficients are equal to those displayed in Table 3 and standard errors only change slightly. 
inequality. Rising education levels, increased female participation, openness -measured as the joint effect of trade and FDI restrictions- and GDP per capita have exerted downward pressure, limiting the overall increase.

Figure 4. Historical decomposition of In(D9/D1) determinants

Contribution to annual change in gross earnings inequality

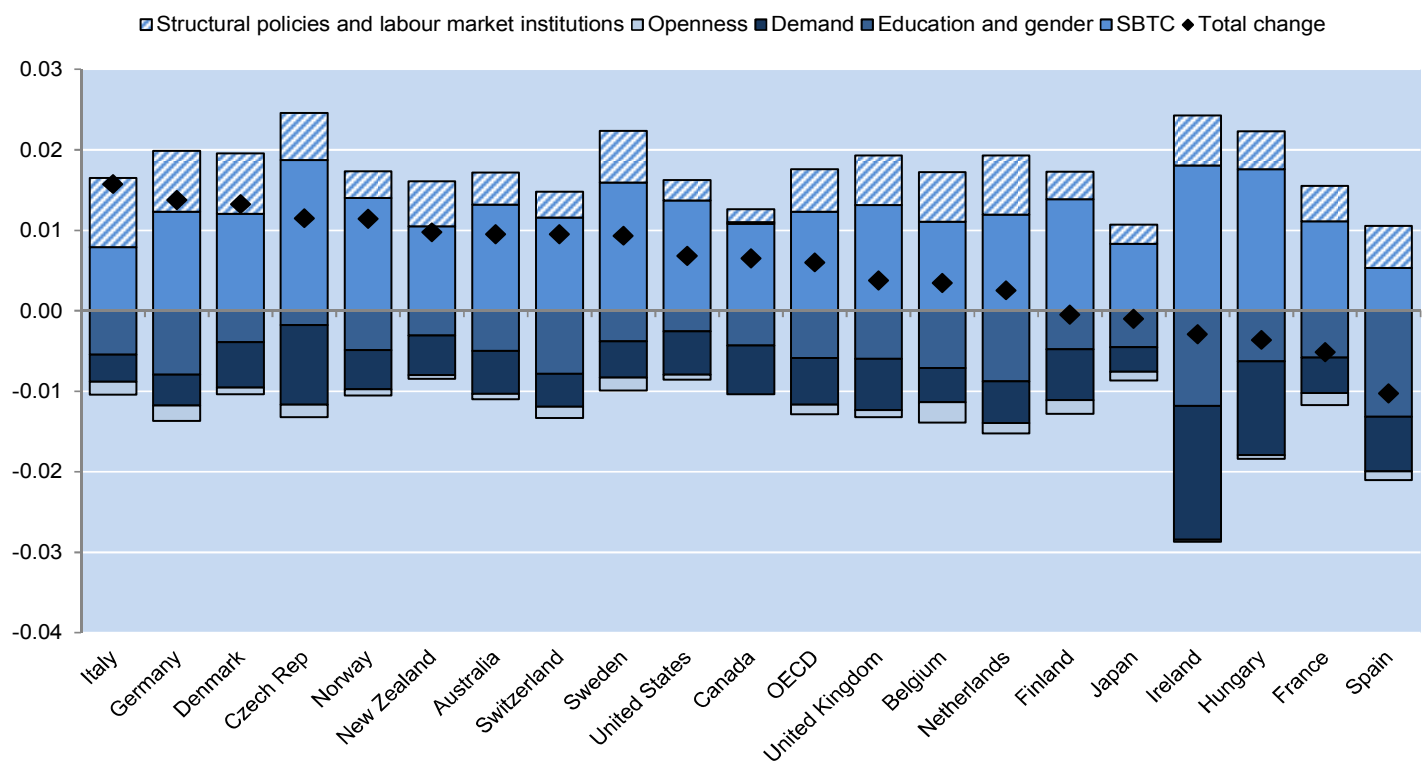

Note: OECD average calculated from the simple average of included countries. Countries included and time coverage as in Table 3 (Augmented Tinbergen - Tested down model, D9/D1). Variables are grouped as follows: Structural policies and labour market institutions (PMR, Union Coverage, EPL, Tax Wedges); Openness (Trade and FDI); Demand (GDP per capita and Cyclical R\&D); Education and Gender (High skill to Low skill ratio and Female participation), SBTC (trend SBTC, MFP, trend R\&D).

40. The joint effect of technology is particularly large for countries that have experienced fast MFP growth, such as Hungary, Ireland and the Czech Republic. On the contrary, this effect is smaller for countries like Spain and Italy where MFP growth was weak. Rising educational attainment levels and the increasing participation of women in the labour market have had an especially large negative effect on earning differentials in Ireland and Spain. Increases in GDP per capita may have helped containing earnings inequality in all countries in the sample, especially in Ireland and the Czech Republic, Hungary and Poland. This effect should not be overemphasized, however, as the influence of GDP per capita is imprecisely estimated.

41. The impact of changing structural policies and labour market institutions on earning differentials has been large in some reforming countries. Product market deregulation has contributed the most to increase earning differentials, especially in the Czech Republic, Spain, Poland, Germany and Denmark. Looser employment protection legislation has also resulted in higher levels of inequality in several countries, particularly in Italy, Sweden, Germany and Belgium. Lower tax wedges have led to increased earning differentials in most countries, remarkably in Ireland and Hungary. Finally, falling union coverage has contributed to rising earning differentials mainly in English-speaking countries and Japan.

\section{Scenario analysis}

42. Coefficient estimates from the D9/D1 model in the first column of Table 3 were used to construct forward-looking scenarios for earnings dispersion up until 2060 that are consistent with the long-term growth scenarios presented in OECD (2014) and trade scenarios from Johansson and Olaberría (2014). 
Since some of the coefficient estimates (e.g. the globalisation variables and, to a lesser extent, GDP per capita) are imprecisely estimated, these scenarios should be considered only indicative. Moreover, any scenarios covering a 50 year time horizon are associated with large uncertainties. A number of alternative scenarios are therefore compared to the baseline scenario as a way to assess the sensitivity of the results.

43. The simulations are static i.e. no endogenous policy responses that could be envisaged as a result of changes in wage dispersion are considered. The assumption of unchanged behaviour can be criticized but it is not as restrictive as it would appear (see Bourguignon and Spadaro, 2006). Moreover, the modelization of such behaviour in forward looking scenarios also entails uncertainties that could significantly weaken the interpretation of dynamic simulations. In any case, results should be interpreted as pointing to the size of the potential redistribution challenges ahead.

\subsection{Baseline scenario}

44. The baseline scenario relies on OECD (2014) long-term projections of MFP and GDP developments based on assumptions about gradual convergence in policies and in educational attainment. ${ }^{20}$ These long-term projections also underlie the trade projections by Johansson and Olaberría (2014), which provide estimates of long-term trade integration developments. Variables that are not considered in OECD (2014) or Johansson and Olaberría (2014), are assumed to stay constant at their most recent available value, save for SBTC that is assumed to continue to follow its estimated historical trend. In line with the empirical results illustrated in previous sections, the expected future rate of global trend SBTC is set at $0.91 \%$ per annum.

45. As discussed in Box 2, economy-wide SBTC has been a pervasive trend since at least the early $20^{\text {th }}$ century, but likely starting a century earlier when modern economic growth started to take-off.

\section{Box 2. How pervasive is skill-biased technological change?}

SBTC has been pervasive in most OECD countries over the past decades. Moreover - aside from cyclical impacts of economic downturns - the annual pace of SBTC has been rather stable. To what extent are these trends likely to prevail?

There is no a priori reason why technological change should always and uniformly be skill-biased across the economy, and there are numerous examples of new technologies (e.g. the assembly line) that specifically have been implemented to replace relatively skilled labour. In manufacture production, there is evidence that technological progress up until the beginning of the $20^{\text {th }}$ century tended to be unskilled-biased, whereas the introduction of continuous-process production and industrial robots since then have pushed technological progress in a skill-biased direction (Mokyr, 2002; Goldin and Katz, 2008). A future abundance of skill-replacing technologies e.g. in terms of analytical capacity from artificial intelligence - could therefore in principle reverse prevailing patterns. Such a development could put downward pressure on earning differentials, but would imply new distributional challenges as the capital share of income would likely rise, as observed in many OECD countries in the past 35 years (Karabarbounis and Neiman, 2013).

In practice, however, modern economic growth seems to have been accompanied by skill-biased technological change in the overall economy. While manufacturing went through the phase of "deskilling" in the $19^{\text {th }}$ century, US evidence suggests that simultaneously rising wage premia and skill-intensity has been the norm for the overall economy as long back as data is available (1820) and when industrialization started (Katz and Margo, 2013). Thus, even though manufacturing became less skill-intensive, a fast-growing service sector increased aggregate relative demand for skilled labour.

Goldin and Katz (2008) give a detailed account of how relative demand for skilled labour (due to SBTC) has evolved since the beginning of the $20^{\text {th }}$ century in the United States. As shown in the table below, there has been a remarkably stable increase in relative demand for college educated workers during the last 100 years.

20. For product market regulations, the baseline scenario assumes that all countries converge to the OECD average levels by 2060. Countries that are already below the OECD average levels in the initial year stay there over the projection horizon. 


\section{Annual increase in relative demand for college-educated workers in the United States}

\begin{tabular}{lccc} 
& $\begin{array}{c}\text { Low elasticity of } \\
\text { substitution }\end{array}$ & $\begin{array}{c}\text { Medium elasticity of } \\
\text { substitution }\end{array}$ & $\begin{array}{c}\text { High elasticity of } \\
\text { substitution }\end{array}$ \\
\hline $1915-40$ & 2.16 & 2.27 & 2.41 \\
$1940-60$ & 1.69 & 1.79 & 1.92 \\
$1960-80$ & 3.73 & 3.73 & 3.74 \\
$1980-2005$ & 3.66 & 3.48 & 3.27 \\
\hline
\end{tabular}

Source: Goldin and Katz (2008). Units: percentage changes

It has been argued that the direction of technological change may be endogenous, reflecting costs of the factor to be replaced and the market size for such a technology. Thus even though skilled labour has become relatively more expensive over time, the size of the market for skill-complementary technologies grows, with the latter effect dominating the former (Acemoglu, 2003). This would mean that if growth in educational attainment slows, technological progress may become less skill-biased. The empirical evidence for such endogenous technological change is, however, limited (Goldin and Katz, 2008).

46. The baseline scenario implies that earning differentials will continue to increase over the coming fifty years, mainly driven by global trend SBTC (Figure 5) ${ }^{21}$. For the OECD average of countries included in the sample over which the augmented Tinbergen model was estimated (left part of the graph in Figure 5 ), increases will be of the order of almost $31 \%$, or an annual increase around $0.62 \%$, which is slightly above the $0.6 \%$ average annual increases observed during the early 1990's to the pre-crisis period for the same OECD countries. Such an increase would push earning differentials in the average OECD country to levels slightly below current levels in the United States (Figure 5, Panel B). Earning inequalities in low inequality countries - like Italy, Sweden and Norway - might by 2060 be equal to those seen in the average OECD country today.

21. In the remainder of the paper, contributions of the various factors to changes in earnings inequality are calculated as the average annual change in the respective covariate multiplied by the corresponding coefficient estimate (as a result, an estimated small coefficient can have a sizeable impact if the associated growth rate of the covariate is large). Non-significant cofficients are considered in order to achieve an exact decomposition. 
Figure 5. Earnings inequality is set to rise further in the baseline scenario

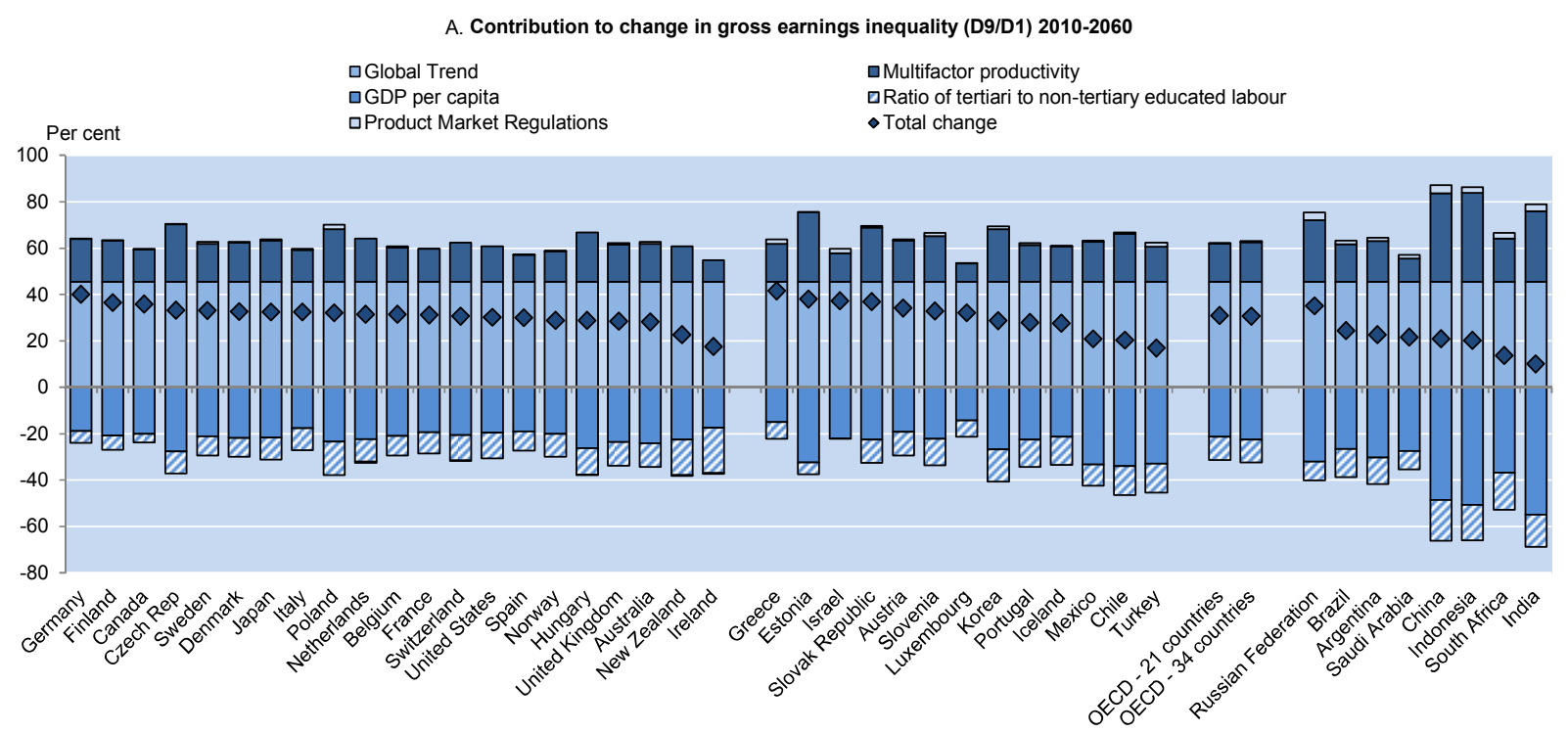

B. Gross earnings inequality (D9/D1), last available year and 2060

aD9/D1, last available year $\quad \diamond D 9 / D 1,2060$ baseline

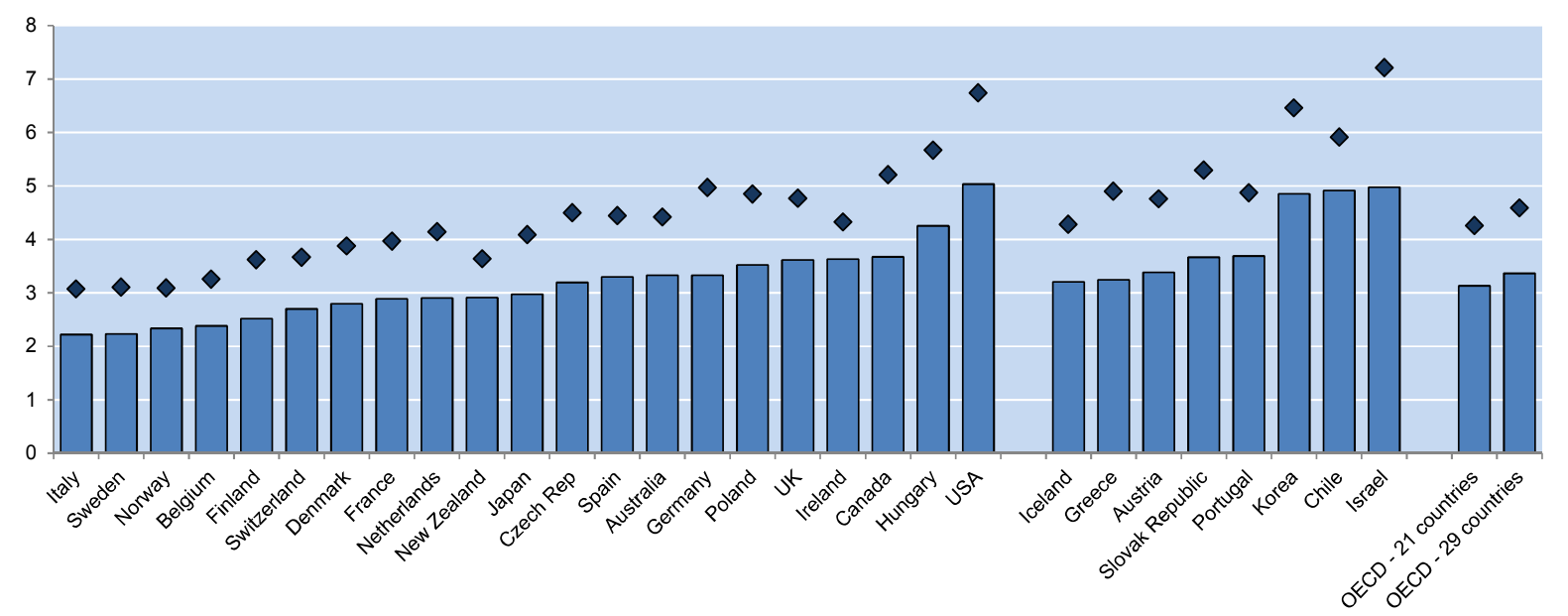

Note: Panel A, countries on the left part of the graph are in-sample countries. OECD -21 countries is computed as the simple average for these 21 OECD countries. Countries on the centre part of the graph are the remaining out-of-sample OECD countries. Countries on the right part of the graph are non-OECD countries with data for explanatory variables (in the baseline scenario) available.

Panel $B$, countries on the left part of the graph are in-sample countries. OECD - 21 countries is computed as the simple average for these 21 OECD countries. Countries on the right part of the graph are out-of-sample countries. OECD 29 countries is computed as the simple average of the countries available. Inequality values in 2060 in Estonia, Luxembourg, Slovenia, Mexico and Turkey (and non-OECD countries) are missing because there is no information available (at the moment of computation) in the OECD Earnings Database for 2010 (or any other recent year), and the series could not be updated with the projected growth rate. Last available year is usually 2010/2011, except for Chile, Czech Republic and France (2009), Iceland (2008) and Netherlands (2005).

47. The OECD average hides significant variation however. Countries experiencing weak increases in educational attainment and with already high levels of GDP per capita in 2010, like Germany, Finland or Canada, may experience an increase in earning differentials close to $40 \%$, while countries with large 
increases in educational attainment (like Ireland and New Zealand) may expect smaller increases in earning differentials (17 and $22 \%$, respectively).

48. Using the simple Tinbergen model (column 1 of Table 1) for these calculations would not change the picture. Earning differentials will continue to increase, with both the OECD average of included countries and the OECD average for all 34 countries experiencing increases of almost $32 \%$ by 2060 . The simple model was used to calculate bounds for inequality developments over the coming fifty years, conditioned on assumptions about the pace of SBTC. If trend SBTC were to increase at an annual rate corresponding to the lower extreme of the $95 \%$ confidence interval around the point estimate in column 1 of Table 1 (that is, at around $0.5 \%$ per year), earning differentials in the average OECD country would increase by $12 \%$ approximately. If trend SBTC were to increase at a faster pace of $1.2 \%$ per year (higher extreme of the $95 \%$ confidence interval), then increases in earning differentials of around $50 \%$ would be seen in the average OECD country.

\section{A specification for other OECD countries and major non-member economies}

49. The model estimated for the 21 OECD countries for which full historical data are available can be used to project earning differentials for 13 additional OECD countries and major non-member economies. These projections have to be treated with additional caution - especially for emerging economies - as economic structures differ significantly from those of countries included in the sample.

50. In the 13 additional countries, earning differentials could increase by between $16 \%$ (Turkey) and $41 \%$ (Greece). For the OECD average including all the 34 member countries, increases in earning differentials would lead inequality to be only slightly below the levels observed now in Korea, Chile, Israel and the United States.

51. Earning differentials could increase by $21 \%$ on average in major non-member economies, although this number masks substantially different developments across countries. Among this group of countries, inequality would increase the most in the Russian Federation, mainly because the increases in both GDP per capita and tertiary education rates are projected to be lower than for the other non-member economies.

\section{Rising earning inequalities will mainly be driven by a divergence in D9/D5 earnings}

52. The model predictions suggest that rising earning inequalities over the coming 50 years will mainly be driven by a divergence in D9/D5 earnings, whereas D5/D1 earning differentials will rise only marginally (Figure 6). For the 21 country OECD average, D9/D5 earning differentials are projected to increase by almost $30 \%$ in the baseline scenario, whereas D5/D1 earning differentials are projected to rise by $2 \%$. Even if the growth rates vary significantly across countries, this divergence in inequality developments across the earnings distribution also holds at the country level. Inequality in the upper part of the distribution may increase the most in Germany (35\%) and the least in Ireland (22\%). Earning differentials in the bottom half of the distribution may also increase the most in Germany (5\%). On the other end, countries like Ireland and New Zealand may experience a slight reduction in D5/D1 earning differentials in the baseline scenario. Results for the additional countries (right part of the figures) are very similar. 
Figure 6. Earnings inequality is driven mainly by a divergence between D9/D5 earnings in the baseline scenario

A. Gross earnings inequality (D9/D5), last available year and 2060

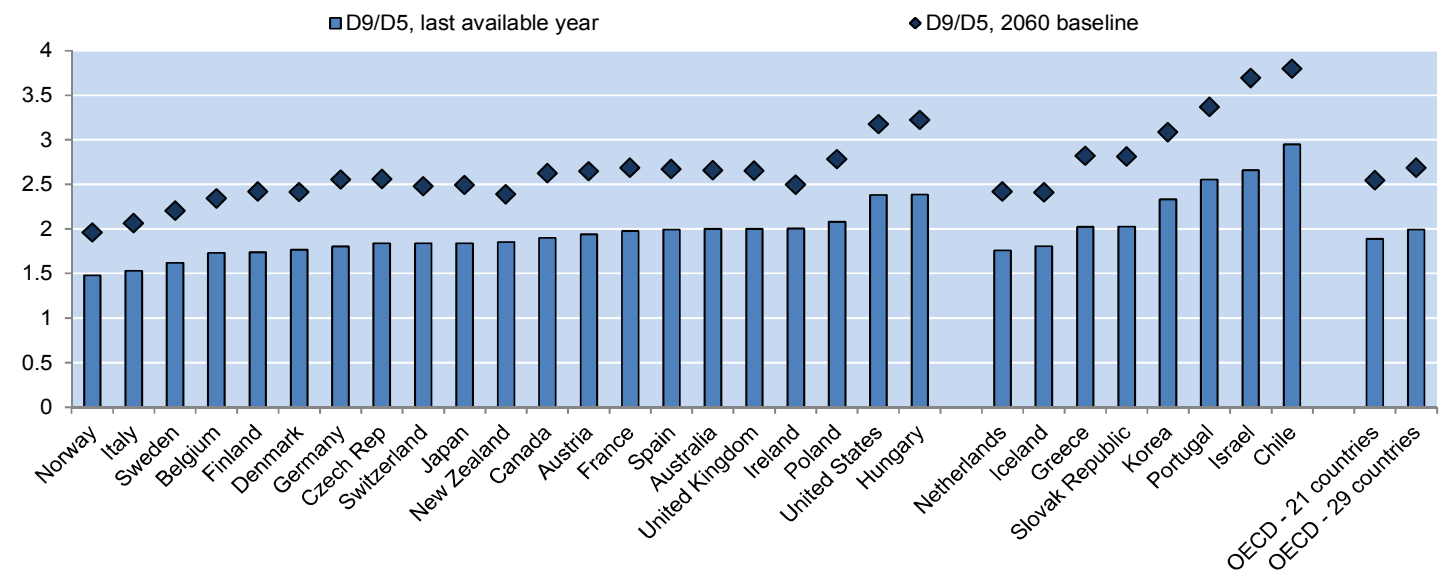

B. Gross earnings inequality (D5/D1), last available year and 2060

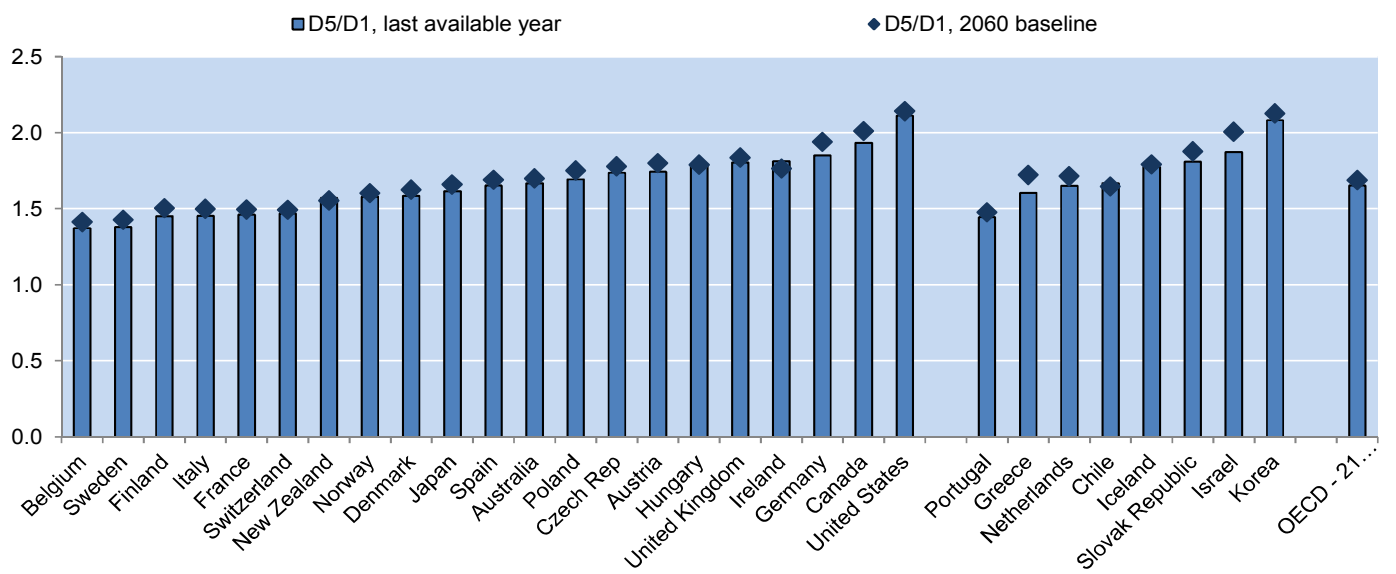

Note: Countries on the left part of the graph are in-sample countries. OECD -21 countries is computed as the simple average for these 21 OECD countries. Countries on the right part of the graph are out-of-sample countries. OECD 29 countries is computed as the simple average of the countries available. Inequality values in 2060 in Estonia, Luxembourg, Slovenia, Mexico and Turkey are missing because there is no information available (at the moment of computation) in the OECD Earnings Database for 2010 (or any other recent year), and the series could not be updated with the projected growth rate. Last available year is usually $2010 / 2011$, except for Chile, Czech Republic and France (2009), Iceland (2008) and Netherlands (2005)

\subsection{Alternative scenario 1: Structural policy settings and labour market institutions move to the least restrictive levels in the sample}

53. Compared to the baseline scenario, in this first alternative scenario structural policies and labour market institutions are assumed to race to the bottom levels in the sample. Country levels of EPL and union coverage are set to converge in 2060 to recent US levels; tax wedges in 2060 to the levels recently observed in New Zealand, and product market regulations are assumed to reach Netherlands recent levels. Remaining variables continue to evolve as in the baseline. 
Figure 7. Increase in earnings inequality (D9/D1) if employment protection, union coverage, tax wedges and PMR are set equal to the lowest levels in the sample

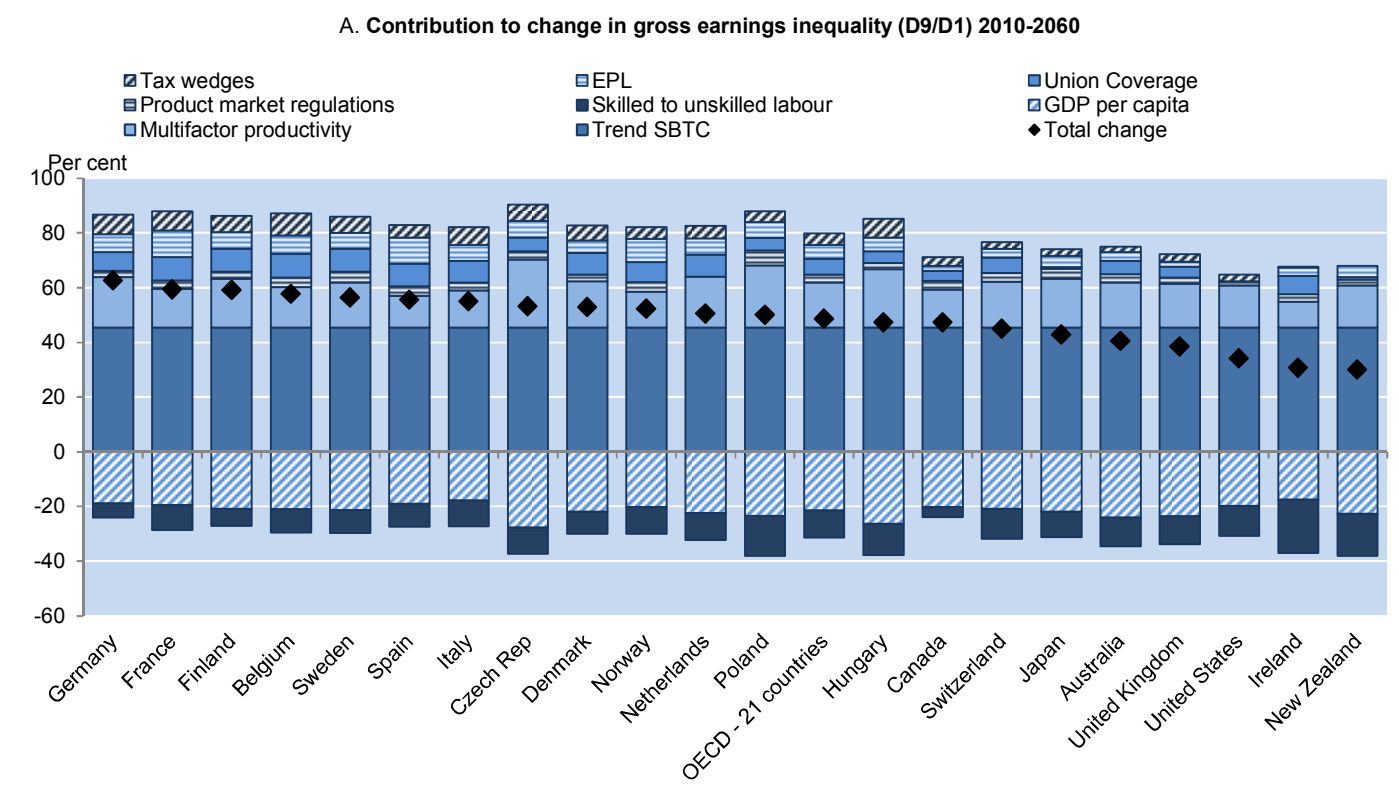

B. Gross earnings inequality (D9/D1) 2010-2060 - baseline and race to bottom scenario

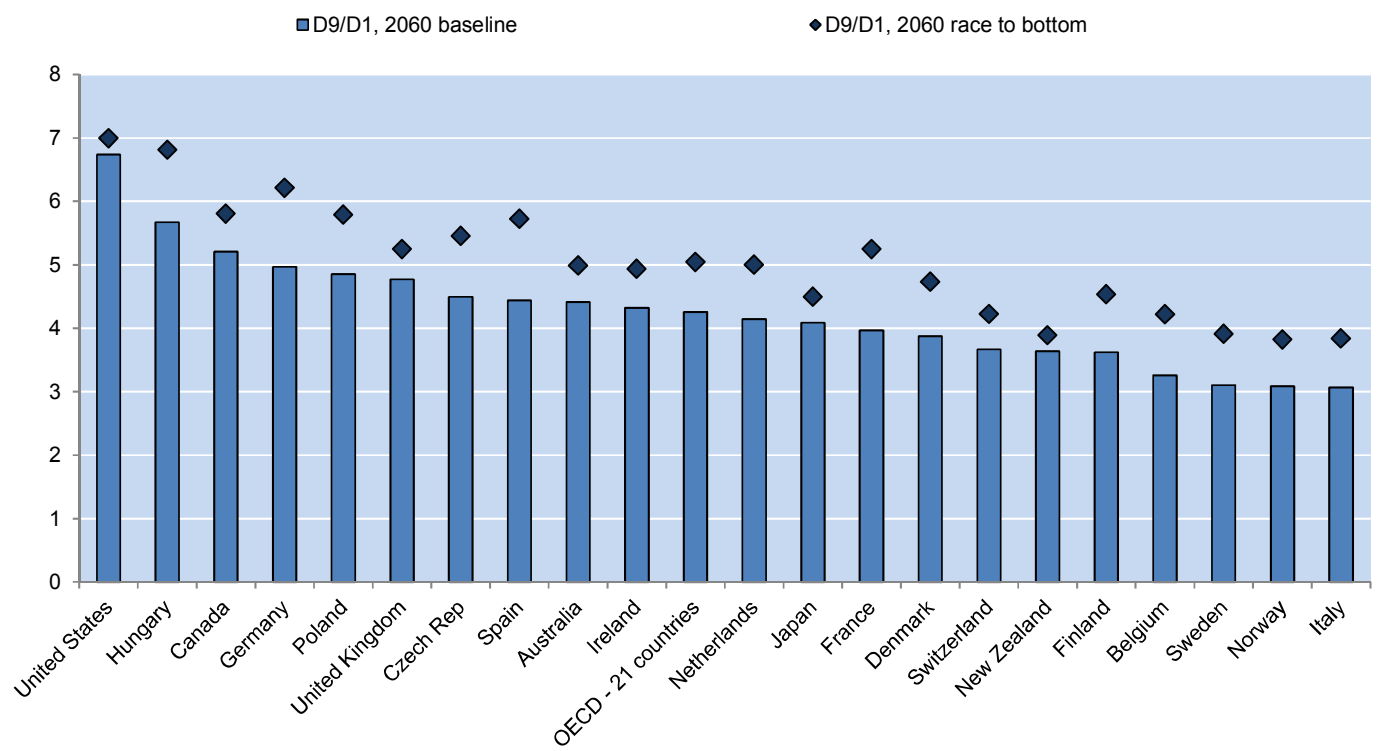

Note: OECD: average of the 21 included countries. Variables racing to the lowest levels for the last available year in the sample. These correspond to: United States (employment protection and union coverage), New Zealand (tax wedges) and Netherlands (PMR).

54. By 2060 , earning differentials for the 21 country OECD average would be $17 \%$ higher in this alternative scenario compared to the baseline (Figure 7). The lowest increase in inequality compared to the baseline scenario would take place in countries that in 2010 already displayed light policy and institutional restrictions. These are mainly the English-speaking countries and Japan. By contrast, some European countries, such as Belgium and France, experience increases in inequality of over $25 \%$ compared to the baseline scenario. Moving towards the situation depicted in this scenario would entail a policy dilemma 
since inequality would increase as compared to the baseline scenario, while the scope for implementing redistributive policies would shrink unless the decrease in income taxation is compensated by a shift towards other sources of revenue or by an increase in the income tax base due to GDP growth.

\subsection{Alternative scenario 2: Structural policy settings and labour market institutions move to the most restrictive levels in the sample}

55. In the second alternative scenario, structural policies and labour market institutions are assumed to converge to the most restrictive levels in the sample (race to the top scenario) as compared to the baseline. Country values for EPL are set to converge in 2060 to levels recently observed in France, tax wedges and union coverage in 2060 to the levels recently observed in Belgium, and product market regulations are set to reach in 2060 the recent levels observed in Poland. As in the previous section, the remaining exogenous variables continue to evolve as in the baseline.

56. Earning differentials increase less than in the baseline scenario in all countries. For the 21 country OECD average, earning differentials in 2060 under this scenario would be almost $14 \%$ lower than in the baseline (Figure 8). Inequality would decrease most relative to baseline in countries displaying low levels of "restrictiveness" in 2010, like the USA or New Zealand, with reductions of around $25 \%$ and $23 \%$, respectively. France and Belgium, with decreases of earning differentials between $4 \%$ and $5 \%$ relative to baseline would experience the smallest reductions in inequality. This scenario as well would entail a policy dilemma as reductions in inequality relative to baseline would require changes in structural policies that would severely harm growth. ${ }^{22}$

\subsection{Alternative scenario 3: Direct and indirect effects of higher trade openness}

57. This alternative scenario explores the impact of higher trade openness on earning differentials. Higher levels of trade openness could affect developments in inequality in two ways: directly, through the effect of increased integration and indirectly through the impact of openness on MFP levels. Increases in openness are based on the "multilateral liberalisation scenario" in Johansson and Olaberría (2014).

58. Earning differentials in 2060 under the higher trade openness scenario do not change substantially compared to the baseline scenario (Figure 9). Inequality would fall marginally for the 21 country OECD average, with the biggest decreases taking place in the Czech Republic and Japan. Panel C in Figure 9 shows that the direct effect of trade integration is dominant.

22. To give a numerical example the assumed tightening in product market regulation would - based on the estimates presented in Johansson et al (2013) - lower GDP by around 20\% on average for the countries in Figure 8 . 
Figure 8. Increase in earnings inequality (D9/D1) if employment protection, union coverage, tax wedges and PMR are set equal to the highest levels in the sample

\section{A. Contribution to change in gross earnings inequality (D9/D1) 2010-2060}

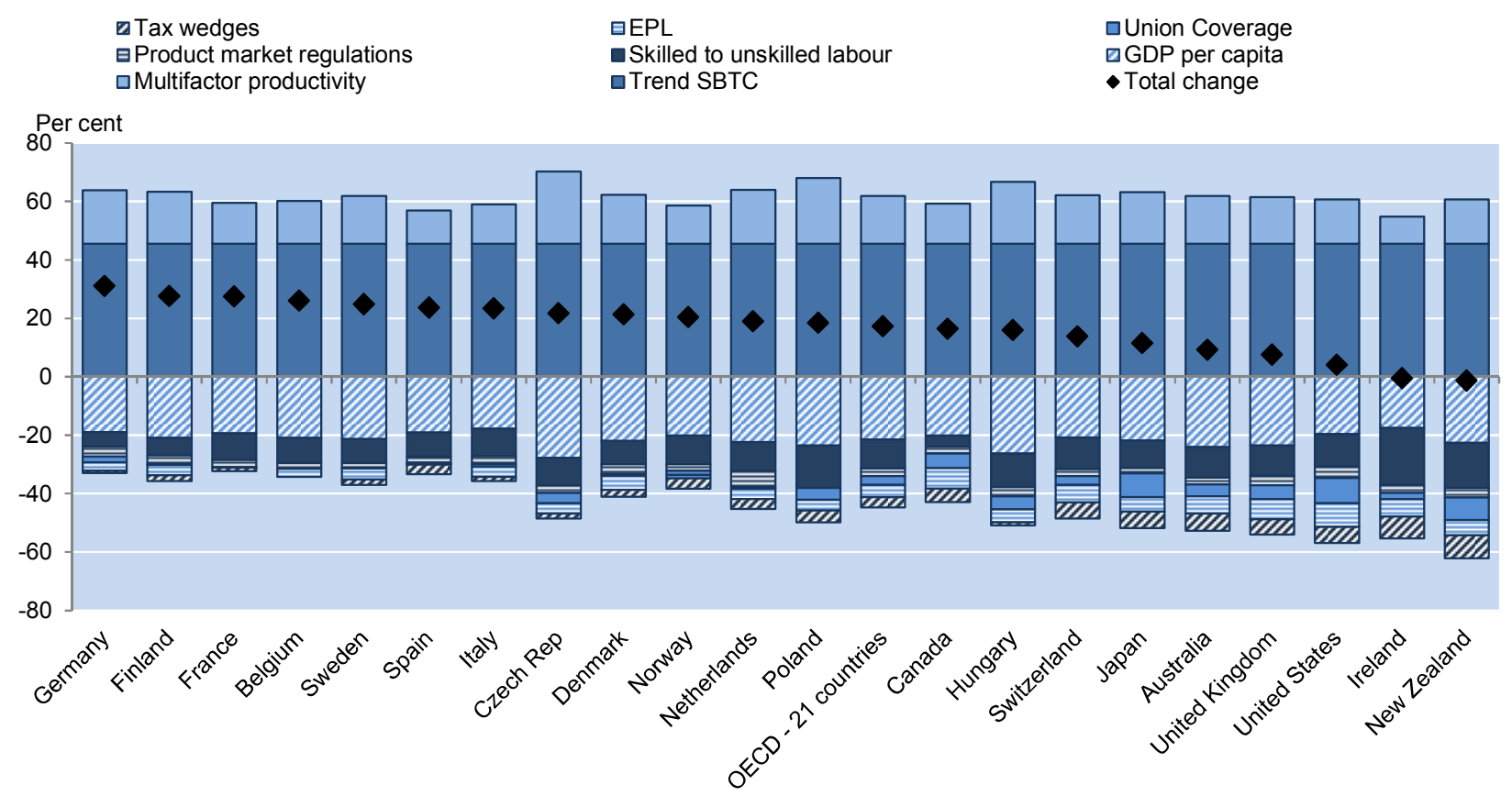

B. Gross earnings inequality (D9/D1) 2010-2060 - baseline and race to the top scenario

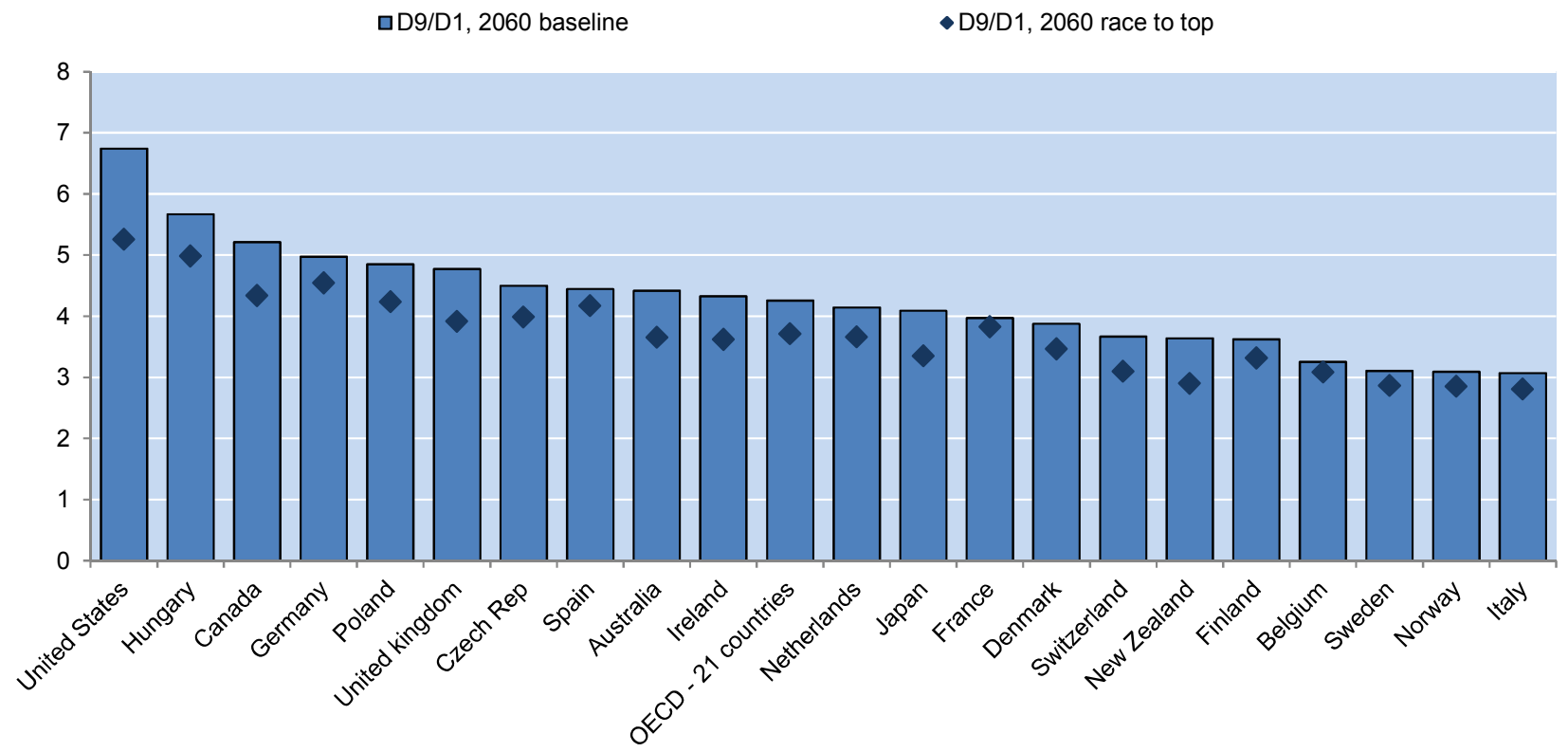

Note: OECD: average of the 21 included countries. Variables racing to the highest levels for the last available year in the sample. These correspond to: France (employment protection), Belgium (union coverage and tax wedges) and Poland (PMR). 
ECO/WKP(2014)35

Figure 9. Increase in earnings inequality (D9/D1) in the trade scenario
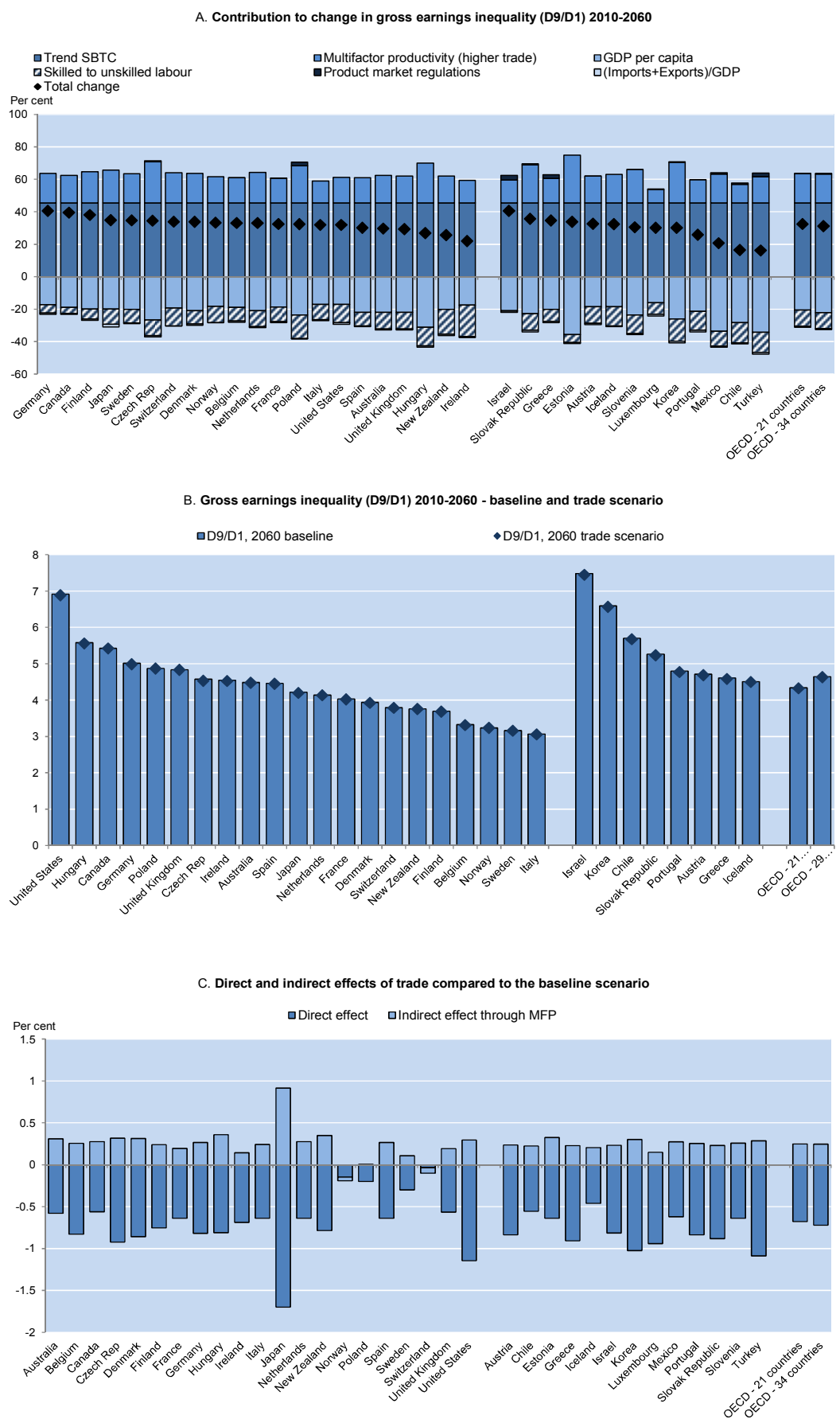

Note: Countries on the left part of the graph are in-sample countries. OECD -21 countries is computed as the simple average for these 21 OECD countries. Countries on the right part of the graph are out-of-sample countries. OECD-34 countries is computed as the simple average for all OECD countries in panel A, and OECD 29 countries is computed as the simple average of the countries available in Panel B. In panel B, inequality values in 2060 in Estonia, Luxembourg, Slovenia, Mexico and Turkey are missing because there is no information available (at the moment of computation) in the OECD Earnings Database for 2010 (or any other recent year), and the series could not be updated with the projected growth rate. Data on (Imports+Exports)/GDP are based on Johansson and Olaberría (2014). 


\subsection{Alternative scenario 4: No increases in inequality due to rising educational attainment}

59. The last scenario calculates the percentage of the population (aged between 25 and 64) which has to have tertiary education in order to counterbalance increases in inequality due to SBTC and other factors. In other words, it computes the share needed in order to maintain inequality in 2060 at the same levels as in 2010. For the 21 OECD countries in the sample, this share should be very close to or above $99 \%$ by 2060 . For the other OECD countries, these shares are also all very high, with the lowest one being close to $90 \%$ in Turkey. Therefore, in order to counterbalance upward pressures on inequality in the baseline scenario, almost all the population (with ages comprised between 25 and 64) would need to complete tertiary education by 2060 in OECD countries. For major non-member countries this is also the case, the exceptions being India (72\%) and South Africa (81\%).

60. This scenario, which is clearly neither realistic nor desirable (as some degree of differentiation in education levels is probably needed), highlights nonetheless the dimension of the policy challenge faced by the world economies that wish to curb the possible increase in inequality over the next decades. 
ECO/WKP(2014)35

\section{REFERENCES}

Acemoglu, D. (2003), "Cross-Country Inequality Trends”, The Economic Journal, Vol. 113/485, Wiley, USA, pp.121-149.

Acemoglu, D. and D. Autor (2012), "What Does Human Capital Do? A Review of Goldin and Katz's The Race between Education and Technology", Journal of Economic Literature, Vol. 50/2, American Economic Association, USA, pp.426-463.

Autor, D. H, D. Dorn, and G.H. Hanson (2013), "The China Syndrome: Local Labor Market Effect of Import Competition in the United States", American Economic Review, Vol. 103/6, American Economic Association, USA, pp.2121-2168.

Autor, D., Katz, L. and M. Kearney (2006), "The Polarization of the U.S. Labor Market", American Economic Review Papers and Proceedings, Vol. 96/2, American Economic Association, USA, pp.189-194.

Autor, D., L. Katz, and M. Kearney (2008), "Trends in U.S. Wage Inequality: Revising the Revisionists", Review of Economics and Statistics, Vol. 90/2, MIT Press Journals, USA, pp.300-323.

Autor, D.H and D. Dorn (2013), "The Growth of Low-Skill Service Jobs and the Polarization of the US Labor Market", American Economic Review, Vol. 103/5, American Economic Association, USA, pp.1553-1597.

Barro R. J., and J.W. Lee (2012), "A New Dataset of Educational Attainment in the World, 1950-2010", Journal of Development Economics, Vol. 104, Elsevier, Amsterdam, pp.184-198.

Bentolila, S., and G. Saint-Paul (2003), "Explaining Movements in the Labor Share", The B.E. Journal of Macroeconomics, De Gruyter, Berlin, Vol. 3/1, pp.1-33.

Bourguignon, F. and A. Spadaro (2006), "Microsimulation as a Tool for Evaluating Redistribution Policies", Journal of Economic Inequality, Vol. 4/1, pp. 77-106.

Braconier, H, Nicoletti, G. and B. Westmore (2014)," Policy Challenges for the Next 50 Years”, OECD Economics Department Policy Papers, No 9, OECD Publishing, Paris.

Campos, J., N. Ericsson, and D. Hendry (2005), "General-to-specific Modelling: An Overview and Selected Bibliography", International Finance Discussion Papers, No. 838, Board of Governors of the Federal Reserve System, USA.

Card, D. (1999), "The causal effect of education on earnings", Handbook of labor economics, Vol.3, Elsevier, Amsterdam, pp.1801-1863.

Card, D. and T. Lemieux (1996), "Wage Dispersion, Returns to Skill, and Black-White Wage Differentials", Journal of Econometrics, Vol.74/2, Elsevier, Amsterdam, pp.319-361.

Causa, O. , S. Araujo, A. Cavaciuti, N. Ruiz and Z. Smidova, (2014a), "Economic Growth from the Household Perspective: GDP and Income Distribution Developments Across OECD Countries", OECD Economics Department Working Papers, No. 1111, OECD Publishing.. 
Causa, O., A. De Serres and N. Ruiz (2014b), "Structural Reforms and Income Distribution", OECD Economics Department Policy Paper, forthcoming.

Cohen, D. and Soto, M (2007), "Growth and Human Capital: Good Data, Good Results", Journal of Economic Growth, Vol.12/1, Springer International Publishing, Switzerland, pp.51-76.

De Santis, R. (2002), "Wage Inequality Between and Within groups: Trade-induced or Skill-bias Technical Change? Alternative age models for the UK", Economic Modelling, Vol. 19/5, Elsevier, Amsterdam, pp.725-746.

Goldin, C. and L. Katz (2008), The Race Between Education and Technology, Harvard University Press, USA.

Gollin, D. (2002), "Getting Income Shares Right", Journal of Political Economy, Vol. 110/2, The University of Chicago Press, USA, pp.458-74.

Goos, M., A. Manning, and A. Salomons (2011), "Explaining Job Polarization: The Roles of Technology, Offshoring and Institutions", Centre for Economic Studies - Discussion Paper Series, No.11.34, Katholieke Universiteit Leuven, pp.1-35.

Griliches, Z. (1969), "Capital-Skill Complementarity", Review of Economics and Statistics, Vol. 51/4, MIT Press Journals, USA, pp.465-468.

Heckman, J., J. Stixrud, and S. Urzua (2006), "The Effects of Cognitive and Non-Cognitive Abilities on Labour Market Outcomes and Social Behaviour", Journal of Labor Economics, Vol. 24/3, University of Chicago Press, USA, pp.411-82.

Heckman, J., L. Lochner, and P. Todd (2006), "Earning Functions, Rates of Return, and Treatment Effects: The Mincer Equation and Beyond", Handbook of the Economics of Education, Vol.1, Elsevier, Amsterdam, pp.307-458.

Hoeller, P., I. Joumard, M. Pisu, and D. Bloch (2012), "Less Income Inequality and More Growth - Are They Compatible? Part 1. Mapping Income Inequality Across the OECD", OECD Economics Department Working Papers, No. 924, OECD Publishing, Paris, http://dx.doi.org/10.1787/5k9h297wxbnr-en

IMF (2007), World Economic Outlook, IMF publishing. Washington D.C.

Jaumotte , F., S. Lall and C. Papageorgiou (2013), "Rising Income Inequality: Technology, or Trade and Financial Globalization?”, IMF Economic Review, Vol.61/2, Palgrave Macmillan, UK, pp.271-309.

Johansson, Å. And E. Olaberría (2014), "Global trade and specialisation patterns over the next 50 years", OECD Economics Department Policy Papers, , OECD Publishing, Paris, forthcoming.

Johansson, A., Y. Guillemette, F. Murtin, D. Turner, G. Nicoletti, C. Maisonneuve, P. Bagnoli, G. Bousquet, and F. Spinelli (2013), "Long-term growth scenarios", OECD Economics Department Working Papers, No.1000, OECD Publishing, Paris, http://dx.doi.org/10.1787/5k4ddxpr2fmr-en

Kalinova, B., A. Palerm and S. Thomsen (2010), "OECD's FDI Restrictiveness Index: 2010 Update”, OECD Working Paper on International Investment, No. 2010/3, OECD Publishing, Paris, http://dx.doi.org/10.1787/5km91p02zj7g-en 
Karabarbounis, L. and B. Neiman (2013), "The Global Decline in the Wage Share”, NBER Working Paper Series, No.19136, National Bureau of Economic Research, USA.

Katz, L. and K. Murphy (1992), "Changes in Relative Wages, 1963-1987: Supply and Demand Factors", Quarterly Journal of Economics, Vol. 107/1, Oxford University Press, UK, pp.35-78.

Katz, L. F. and R. A. Margo (2013), "Technical Change and the Relative Demand for Skilled Labor: The United States in Historical Perspective", NBER Working Paper Series, No.18752, National Bureau of Economic Research, USA.

Koeniger, W. and L. Nunziata (2007), "Labour Market Institutions and Wage Inequality", Industrial and Labour Relations Review, Vol. 60/3, Cornell University, USA, pp.340-356.

Koske, I., J. Fournier and I. Wanner (2012), "Less Income Inequality and More Growth - Are They Compatible? Part 2. The Distribution of Labour Income", OECD Economics Department Working Papers, No. 925, OECD Publishing, Paris, http://dx.doi.org/10.1787/5k9h2975rhhf-en

Krusell, P., L. E. Ohanian, J. V. Ríos-Rull, and G. L. Violante (2000), "Capital-skill Complementarity and Inequality: A Macroeconomic Analysis”, Econometrica, Vol. 68/5, Wiley, USA, pp.1029-1053.

Mokyr, J. (2002), The Gifts of Athena: Historical Origins of the Knowledge Economy, Princeton University Press, USA.

OECD (2008), Growing Unequal? Income distribution and Poverty in OECD Countries, OECD publishing, Paris. http://dx.doi.org/10.1787/9789264044197-en

OECD (2011), Divided We Stand: Why Inequality Keeps Rising, OECD publishing, http://dx.doi.org/10.1787/9789264119536-en

OECD (2014), OECD Economic Outlook, Vol. 2014/1, OECD Publishing, Paris, http://dx.doi.org/10.1787/eco_outlook-v2014-1-en

Piketty, T., and Zucman, G. (2013). "Capital is back: Wealth-income ratios in rich countries 1700-2010", http://piketty.pse.ens.fr/files/PikettyZucman2013WP.pdf

Rosnick, D., \& Baker, D. (2012). "Missing the Story: The OECD's Analysis of Inequality”, Center for Economic and Policy Research (CEPR), USA.

Saez, E. (2013). "Striking it Richer: The Evolution of Top Incomes in the United States (Updated with 2012 preliminary estimates)", University of California, Berkeley, http://128.32.105.3/ saez/saezUStopincomes-2012.pdf

Tinbergen, J. (1974), "Substitution of Graduate by other Labour”, Kyklos, Vol. 27/2, Wily, USA, pp.21726.

Visser, J. (2009), "The ICTWSS Database: Database on Institutional Characteristics of Trade Unions, Wage Setting, State Intervention and Social Pacts in 34 Countries between 1960 and 2007”, Amsterdam Institute for Advanced Labour Studies (AIAS), http://www.uva-aias.net/208 


\section{APPENDIX 1: DATA AND DEFINITION OF VARIABLES}

1. Table A1.1 below describes the independent variables used throughout the analysis. Most of them are the same used in OECD (2011).

Table A1.1 Explanatory variables and data sources

\begin{tabular}{lll} 
Name & Description & Source \\
\hline $\begin{array}{l}\text { Multifactor } \\
\text { productivity (MFP) }\end{array}$ & $\begin{array}{l}\text { It is constructed as LABEFF } \\
\text { Labour Efficiency (in volume 2005 USD) }\end{array}$ & $\begin{array}{l}\text { OECD's Economic Outlook and OECD's long } \\
\text { term baseline scenario }\end{array}$ \\
\hline Capital intensity & $\begin{array}{l}\text { (Gross fixed capital formation - Gross fixed capital } \\
\text { formation, housing) divided by GDP (all variables in } \\
\text { volume 2005 USD) }\end{array}$ & $\begin{array}{l}\text { OECD's Economic Outlook and OECD's long } \\
\text { term baseline scenario }\end{array}$ \\
\hline Business R\&D & $\begin{array}{l}\text { Business sector expenditure on R\&D over GDP. The trend } \\
\text { and cyclical components of this variable, after applying the } \\
\text { Hodrick-Prescott filter using a smoothing parameter of } \\
\text { 6.25 for annual data (as in OECD 2011), have been used } \\
\text { in the analysis }\end{array}$ & OECD Science and Technology Indicators \\
\hline $\begin{array}{l}\text { GDP per capita } \\
\text { (GDP pc) }\end{array}$ & $\begin{array}{l}\text { Gross domestic product per capita (in volume and 2005 } \\
\text { USD) }\end{array}$ & $\begin{array}{l}\text { OECD's Economic Outlook and OECD's long } \\
\text { term baseline scenario }\end{array}$ \\
\hline Trade & Exports plus imports over GDP & OECD STAN database \\
\hline
\end{tabular}

FDI restrictiveness index: de jure FDI measure which takes a value between 0 (open) and 1 (closed). The index covers four types of financial regulations: i) foreign equity restrictions, ii) screening and prior approval requirements, iii) rules for key personnel, and iv) other restrictions on the operation of foreign enterprises (see Kalinova et al., 2010). The consistency of sources used in constructing the FDI restrictiveness index makes it possible to track the progress of financial investment liberalisation over time

\section{OECD FDI Index} index

Percentage of Gross Value Added going to the compensation of employees in the financial sector

OECD Statistics

$\begin{array}{ll}\text { Financial } & \text { compensation } \\ \text { Compation of employees in the financial sector }\end{array}$

Constructed as $\mathrm{HS} /(1-\mathrm{HS})$, and where $\mathrm{HS}=\%$ of population that has post-secondary education. Data from 2001-2008 comes from OECD Education at a Glance. High skill to low skill Previous data comes from Barro and Lee (2000) dataset. ratio (HS/LS) OECD projections (up to 2060) based on Soto and Cohen (2007) and Barro and Lee (2000). Except data from OECD at a glance, for the other years, data are linearly interpolated
Barro and Lee (2000), OECD Education at a

Glance and OECD projections based on Soto and Cohen (2007) and Barro and Lee (2000)

$$
\text { Women as a \% of total employment }
$$

From 0 - 6 (least to most restrictions). The indicators in

Product Market Regulations (PMR) energy, transport and communications (ETCR) summarise regulatory provisions in seven sectors: telecoms, electricity, gas, post, rail , air passenger transport, and road freight.
OECD PMR indicators, and OECD's long term baseline scenario 


\begin{tabular}{lll} 
Union Coverage & $\begin{array}{l}\text { The variable "AdjCov"from Visser (2009). From 0 - 100. It } \\
\text { refers to employees covered by wage bargaining } \\
\text { agreements as a proportion of all wage and salary earners } \\
\text { in employment with the right to bargaining }\end{array}$ & $\begin{array}{l}\text { Database on Institutional Characteristics of Trade } \\
\text { Unions, Wage Setting, State Intervention and } \\
\text { Social Pacts (ICTWSS) }\end{array}$ \\
\hline $\begin{array}{l}\text { Employment } \\
\text { protection } \\
\text { legislation (EPL) }\end{array}$ & From 0 - 6 (least to most restrictions) & OECD Employment Database \\
\hline & $\begin{array}{l}\text { Tax wedges are calculated by expressing the sum of } \\
\text { personal income tax, employee plus employer social } \\
\text { security contributions and payroll tax, as a percentage of } \\
\text { labour costs (gross wages + employer social security } \\
\text { contributions and payroll taxes). The reference rates are } \\
\text { for single person without children at 100\% of the average } \\
\text { level }\end{array}$ & OECD Taxing Wedges \\
\hline Tax Wedges & $\begin{array}{l}\text { Output gap between actual and potential output as a \% of } \\
\text { potential output }\end{array}$ & $\begin{array}{l}\text { OECD's Economic Outlook and OECD's long } \\
\text { term baseline scenario }\end{array}$ \\
\hline Output gap & $\begin{array}{l}\text { Sectoral growth rate in value added, multiplied by share in } \\
\text { total hours worked by high-skill persons engaged }\end{array}$ & WIOD database \\
\hline $\begin{array}{l}\text { Specialization } \\
\text { (SBSPEC) }\end{array}$ & & \\
\hline
\end{tabular}

\section{The dependent variable: gross earning differentials and other wage measures}

2. The dependent variables used in the analysis are the decile ratios of gross earnings (D9/D1, D9/D5, D5/D1) compiled by the OECD in the OECD Earnings Database. The data is available for OECD countries and the time coverage differs across countries. A major drawback of using this data is that earnings are not directly mapped into levels of acquired education, which is what the Tinbergen model models. However, while the length of acquired education is an important contributor to "skills", quality aspects of education and non-education factors also contribute. Recent evidence also points to an increasing role of non-educational factors in explaining earning differentials (Card and Lemieux, 1996). Furthermore, there is a lack of high-quality education-based earnings data suitable for cross-country analysis. Initially, the analysis was also performed using education-based wage data from the WIODdatabase, but overall fit was low. Given that the WIOD-data on wage by occupation is not constructed for cross-country comparison, this line of analysis was dropped. ${ }^{23}$

3. Table A1.2 describes the set of countries and time period covered in the tables and figures in the main paper.

23. The WIOD earnings data is to a large extent based on EU KLEMS. The EU KLEMS methodology handbook (March 2007) states that “...educational attainment as a measure of skill, using a rigid highmedium-low skill split, which will be too restrictive for comparisons across countries, but is useful for tracking developments over time in a particular country". 
Table A1.2 First and last year available in the tables and figures throughout the document

\begin{tabular}{|c|c|c|c|c|c|c|}
\hline & \multicolumn{2}{|c|}{ Tinbergen model ${ }^{*}$} & \multicolumn{2}{|c|}{ Augmented Tinbergen model } & \multicolumn{2}{|c|}{$\begin{array}{c}\text { Augmented Tinbergen -tested } \\
\text { down models }\end{array}$} \\
\hline & D9/D1 & D9/D5 \& D5/D1 & D9/D1 & D9/D5 \& D5/D1 & D9/D1 & D9/D5 \& D5/D1 \\
\hline Australia & $1979 / 2008$ & $1979 / 2008$ & $1990 / 2006$ & $1990 / 2006$ & $1990 / 2006$ & $1990 / 2006$ \\
\hline Austria & $1980 / 1994$ & $2004 / 2008$ & -- & $2004 / 2006$ & -- & $2004 / 2006$ \\
\hline Belgium & $1986 / 2007$ & $1999 / 2008$ & $1990 / 2006$ & $1999 / 2006$ & $1990 / 2006$ & $1999 / 2006$ \\
\hline Canada & $1997 / 2008$ & $1997 / 2008$ & $1997 / 2006$ & $1997 / 2006$ & $1997 / 2006$ & $1997 / 2006$ \\
\hline Czech Republic & $1996 / 2008$ & $1996 / 2008$ & $2000 / 2006$ & $2000 / 2006$ & $2000 / 2006$ & $2000 / 2006$ \\
\hline Denmark & $1980 / 2008$ & $1980 / 2008$ & $1990 / 2006$ & $1990 / 2006$ & $1990 / 2006$ & $1990 / 2006$ \\
\hline Finland & $1980 / 2008$ & $1979 / 2008$ & $1990 / 2006$ & $1990 / 2006$ & $1990 / 2006$ & $1990 / 2006$ \\
\hline France & $1979 / 2007$ & $1979 / 2008$ & $1994 / 2006$ & $1994 / 2006$ & $1994 / 2006$ & $1994 / 2006$ \\
\hline Germany & $1984 / 2008$ & $1992 / 2008$ & $1990 / 2006$ & $1992 / 2006$ & $1990 / 2006$ & $1992 / 2006$ \\
\hline Hungary & $1992 / 2008$ & $1986 / 2008$ & $2000 / 2006$ & $2000 / 2006$ & $2000 / 2006$ & $2000 / 2006$ \\
\hline Ireland & $1994 / 2008$ & $1994 / 2008$ & $1994 / 2006$ & $1994 / 2006$ & $1994 / 2006$ & $1994 / 2006$ \\
\hline Italy & $1986 / 2006$ & $1986 / 2008$ & $1990 / 2006$ & $1990 / 2006$ & $1990 / 2006$ & $1990 / 2006$ \\
\hline Japan & $1979 / 2008$ & $1979 / 2008$ & $1990 / 2006$ & $1990 / 2006$ & $1990 / 2006$ & $1990 / 2006$ \\
\hline Korea & $1984 / 2008$ & $1984 / 2008$ & -- & -- & -- & -- \\
\hline Netherlands & $1979 / 2005$ & -- & $1990 / 2005$ & -- & $1990 / 2005$ & -- \\
\hline New Zealand & $1984 / 1985$ & $1984 / 2008$ & $1990 / 2006$ & $1990 / 2006$ & $1990 / 2006$ & $1990 / 2006$ \\
\hline Norway & $1997 / 2008$ & $1997 / 2008$ & -- & -- & $1997 / 2006$ & $1997 / 2006$ \\
\hline Poland & $1992 / 2008$ & $2005 / 2008$ & $2000 / 2006$ & $2005 / 2006$ & $2000 / 2006$ & $2005 / 2006$ \\
\hline Spain & $1994 / 2008$ & $2004 / 2008$ & $1994 / 2006$ & $2004 / 2006$ & $1994 / 2006$ & $2004 / 2006$ \\
\hline Sweden & $1980 / 2008$ & $1979 / 2008$ & $1993 / 2006$ & $1993 / 2006$ & $1990 / 2006$ & $1990 / 2006$ \\
\hline Switzerland & $1996 / 2008$ & $1996 / 2008$ & -- & -- & $1996 / 2006$ & $1996 / 2006$ \\
\hline United Kingdom & $1979 / 2008$ & $1979 / 2008$ & $1990 / 2006$ & $1990 / 2006$ & $1990 / 2006$ & $1990 / 2006$ \\
\hline United States & $1979 / 2008$ & $1979 / 2008$ & $1990 / 2006$ & $1990 / 2006$ & $1990 / 2006$ & $1990 / 2006$ \\
\hline
\end{tabular}

Note: *Starts in 1985 for those countries with data available before 1985, as long as MFP is included (Table 1 column 2, and Fig 3panels $A$ and $C$ ) 
ECO/WKP(2014)35

APPENDIX 2: RESULTS OF THE JOINT ESTIMATION OF LOG (D9/D5) AND LOG (D5/D1)

Table A2.1 Joint estimation of $\ln (D 9 / D 5)$ and $\ln (D 5 / D 1)$

\begin{tabular}{|c|c|c|}
\hline & $\begin{array}{c}\ln (\mathrm{D} 9 / \mathrm{D} 5) \\
\beta / \text { t-stat }\end{array}$ & $\begin{array}{c}\ln (\mathrm{D} 5 / \mathrm{D} 1) \\
\beta / t-s t a t\end{array}$ \\
\hline Trend SBTC & $\begin{array}{c}0.007^{* * *} \\
(3.71)\end{array}$ & $\begin{array}{l}0.002 \\
(0.62)\end{array}$ \\
\hline In (MFP) & $\begin{array}{l}0.188^{*} \\
(1.84)\end{array}$ & $\begin{array}{l}0.076 \\
(0.73)\end{array}$ \\
\hline In (Trend R \& D) & $\begin{array}{l}-0.002 \\
(-0.22)\end{array}$ & $\begin{array}{c}0.041^{\text {***}} \\
(2.43)\end{array}$ \\
\hline In (GDP pc) & $\begin{array}{l}-0.096 \\
(-0.89)\end{array}$ & $\begin{array}{l}-0.074 \\
(-0.67)\end{array}$ \\
\hline In (Trade) & $\begin{array}{c}-0.055^{\star \star *} \\
(-2.95)\end{array}$ & $\begin{array}{l}-0.028 \\
(-0.71)\end{array}$ \\
\hline In (FDI restrictiveness index) & $\begin{array}{c}-0.028^{*} \\
(-1.66)\end{array}$ & $\begin{array}{c}0.087^{* * *} \\
(3.42)\end{array}$ \\
\hline Cyclical R \& D & $\begin{array}{c}0.001^{* * *} \\
(3.64)\end{array}$ & $\begin{array}{l}0.000 \\
(0.98)\end{array}$ \\
\hline $\ln (\mathrm{HS} / \mathrm{LS})$ & $\begin{array}{c}-0.041^{\star \star \star} \\
(-2.14)\end{array}$ & $\begin{array}{c}-0.025^{*} \\
(-1.93)\end{array}$ \\
\hline In (Female Participation) & $\begin{array}{l}0.029 \\
(0.15)\end{array}$ & $\begin{array}{c}-0.423^{* * *} \\
(-2.43)\end{array}$ \\
\hline In (PMR) & $\begin{array}{l}0.022 \\
(1.47)\end{array}$ & $\begin{array}{c}-0.092^{* * *} \\
(-4.17)\end{array}$ \\
\hline In (Union Coverage) & $\begin{array}{c}-0.049^{* * *} \\
(-3.24)\end{array}$ & $\begin{array}{l}0.021 \\
(0.94)\end{array}$ \\
\hline EPL & $\begin{array}{c}0.000 \\
(-0.02)\end{array}$ & $\begin{array}{c}-0.033^{* * *} \\
(-2.18)\end{array}$ \\
\hline In (Tax Wedges) & $\begin{array}{l}-0.023 \\
(-0.64) \\
\end{array}$ & $\begin{array}{c}-0.069^{* * *} \\
(-2.01) \\
\end{array}$ \\
\hline Number of observations & \multicolumn{2}{|c|}{246} \\
\hline Number of countries & \multicolumn{2}{|c|}{21} \\
\hline $\operatorname{Cov}(\mathrm{e}-\ln (\mathrm{D} 9 / \mathrm{D} 5), \mathrm{e}-\ln (\mathrm{D} 5 / \mathrm{D} 1))$ & \multicolumn{2}{|c|}{$\begin{array}{c}0.0000309 \\
(1.140)\end{array}$} \\
\hline
\end{tabular}

Note: Equations estimated jointly as seemingly unrelated regression equations (SURE), using the structural equation command (sem) in Stata that allows for the errors in both equations to be correlated. Standard errors adjusted for number of clusters (countries). * ${ }^{* *}$, *** denote significance at the 10,5 and 1 per cent level, respectively. Countries included and time coverage as in Table A1.2 in Appendix 1 
ECO/WKP(2014)35

\section{WORKING PAPERS}

The full series of Economics Department Working Papers can be consulted at www.oecd.org/eco/workingpapers

1138. Determinants of tertiary graduations

(July 2014) by Henrik Braconier

1137. Managerial capital and business $R \& D$ as enablers of productivity convergence

(July 2014) by Dan Andrews and Ben Westmore

1136. Long-term Patterns of Trade and Specialisation

(July 2014) by Åsa Johansson, and Eduardo Olabberia

1135. Consequences of climate change damages for economic growth - a dynamic quantitative assessment

(July 2014) by Rob Dellink, Elisa Lanzi, Jean Chateau, Francesco Bosello, Ramiro Parrado and Kelly de Bruin

1136. Long-term patterns of trade and specialisation

(July 2014) by Asa Johansson and Eduardo Olaberría

1135. Consequences of climate change damages for economic growth - a dynamic quantitative assessment

(July 2014) by Rob Dellink, Elisa Lanzi, Jean Chateau, Francesco Bosello, Ramiro Parrado and Kelly de Bruin

1134. Comparing the robustness of PAYG pension schemes

(July 2014) by Falilou Fall

1133. Overcoming vulnerabilities of pension systems

(July 2014) by Falilou Fall and Debbie Bloch

1132. Overcoming vulnerabilities of health care systems

(July 2014) by Mauro Pisu

1131. Overcoming vulnerability of unemployment insurance schemes

(July 2014) by Jon Pareliussen

1130. Vulnerability of social institutions: Lessons from the recent crisis and historical episodes (July 2014) by Falilou Fall, Mauro Pisu, Jon Pareliussen and Debbie Bloch

1129. An update of the OECD international trade equations

(June 2014) by Myriam Morin and Cyrille Schwellnus

1128. What explains the volume and composition of trade? Industrial evidence from a panel of countries

(June 2014) by Asa Johansson, Przemyslaw Kowalski, Eduardo Olaberría and Dario Pellegrino

1127. Do resources flow to patenting firms: cross-country evidence from firm level data

(June 2014) by Dan Andrews, Chiara Criscuolo and Carlo Menon 
1126. Macroprudential policy tools in Norway: Strengthening financial system resilience (June 2014) by Yosuke Jin, Patrick Lenain and Paul O’Brien

1125. Strengthening competition in Poland

(June 2014) by Balász Égert and Antoine Goujard

1124. Making the labour market work better in Poland (June 2014) by Hervé Boulhol

1123. Enhancing competition and the business environment in Hungary (June 2014) by Alvaro Pina

1122. Tackling labour mismatches and promoting mobility in Hungary (June 2014) by Stéphane Sorbe

1121. Local public finances and municipal reform in Finland (June 2014) by Christophe André and Clara Garcia

1120. The economic consequences of ageing: the case of Finland (June 2014) by Christine de la Maisonneuve, Christophe André, Clara Garcia and Vincent Koen

1119. Making the most of skills in Denmark (June 2014) by Stéphanie Jamet and Vincent Koen

1118. Trade specialisation and policies to foster competition and innovation in Denmark (June 2014) by Müge Adalet McGowan

1117. Policies for making the Chilean labour market more inclusive (June 2014) by Aida Caldera Sanchez

1116. Spillover effects from exiting highly expansionary monetary policies (May 2014) by Łukasz Rawdanowicz, Romain Bouis, Jérôme Brezillon, Ane Kathrine Christensen and Kei-Ichiro Inaba

1115. Economic policies and microeconomic stability: A literature review and some empirics (April 2014) by Paula Garda and Volker Ziemann

1114. How to improve Israel's health-care system (April 2014) by Philip Hemmings 